\title{
Chemical and Oxygen Isotopic Composition of Roman and Late Antique Glass from Northern Greece
}

\author{
Alberta Silvestri, ${ }^{1}$ Elissavet Dotsika, ${ }^{2,3}$ Antonio Longinelli, ${ }^{4}$ \\ Enricomaria Selmo, ${ }^{4}$ and Sophia Doukata-Demertzi ${ }^{5}$ \\ ${ }^{1}$ Department of Geosciences, University of Padova, Via G. Gradenigo 6, 35131 Padova, Italy \\ ${ }^{2}$ Institute of Material Science, Stable Isotope Unit, NCSR "Demokritos", Aghia Paraskevi, 15310 Attiki, Greece \\ ${ }^{3}$ Institute of Geosciences and Earth Resources, CNR, Via G. Moruzzi 1, 56124 Pisa, Italy \\ ${ }^{4}$ Department of Physics and Earth Sciences, University of Parma, Via G.P. Usberti 157A, 43100 Parma, Italy \\ ${ }^{5} 12$ th Ephorate of Byzantine Antiquities, General Directorate of Antiquities and Cultural Heritage, Athens, Greece
}

Correspondence should be addressed to Elissavet Dotsika; e.dotsika@inn.demokritos.gr

Received 15 November 2016; Accepted 8 March 2017; Published 18 April 2017

Academic Editor: Kaustubha Mohanty

Copyright (C) 2017 Alberta Silvestri et al. This is an open access article distributed under the Creative Commons Attribution License, which permits unrestricted use, distribution, and reproduction in any medium, provided the original work is properly cited.

\begin{abstract}
The present paper emphasizes the importance of measuring the oxygen isotopic and chemical compositions of ancient glass, in order to constrain some features such as age, raw materials, and production technologies and to identify the "fingerprint" of local productions. In this context, thirty-nine Roman and late Antique glass samples and eight chert samples from northern Greece were selected and analysed for their oxygen isotopic and chemical compositions. Results show that the majority of glass samples are produced using natron as flux and have $\delta^{18} \mathrm{O}$ values of about $15.5 \%$, plus or minus a few tenths of one per mil, suggesting that raw materials probably come from Levantine area. Four samples are heavily enriched in ${ }^{18} \mathrm{O}$, and their chemical composition clearly shows that they were made with soda plant ash as flux. Isotopic and chemical data of Greek chert samples support the hypothesis of local production of the above samples. About half of the glass samples have chemical compositions, which allow their age to be constrained to the late Antique period. For the remaining glass, similarities with literature compositional groups are reported and discussed.
\end{abstract}

\section{Introduction}

It is well-known that, at different periods of history, glass was produced by adding a flux, composed of natron (term here adopted with the meaning of usually complex, often polyphase evaporitic deposits rich in carbonates of sodium), or soda ash from the combustion of halophytic plants such as Salsola or Salicornia, or potash ash from the combustion of trees such as beech, birch, and oak, to quartz pebbles or quartz-limestone sand [1]. The use of these different raw materials influences not only final chemical compositions of the resulting glass [1], but also the oxygen isotopic compositions. The addition of natron during melting normally causes ${ }^{18} \mathrm{O}$ enrichment in final glass, at least when natron from the evaporitic lakes of Wadi Natrun in Egypt is used, as its oxygen isotopic composition is heavily enriched in ${ }^{18} \mathrm{O}[2,3]$. The ash should not greatly affect oxygen isotopic composition of glass, which reflects that of the network former (normally $\mathrm{SiO}_{2}$, added to the batch in the form of quartz pebbles or quartz-limestone sand) [3], although Tite et al. [4] stated that ash, when relatively rich in carbonates, bicarbonates, and hydrates, may cause some isotopic changes in final product.

In this context, the existence in Greece of locally produced glass vessels [5], as well as the import and trade of raw glass and glass artefacts, probably produced in Near East or Middle East countries, draws attention to the importance of identifying the "fingerprint" of Roman and late Antique glass made in Greece, of distinguishing raw materials and fluxes used for glass melting, of defining production technologies, and, indirectly, of better constraining the age of analysed objects. Measurements of oxygen isotopic and chemical compositions of glass samples and possible raw materials seem 
promising tools to advance in this direction. To the best of our knowledge, the present paper is the first contribution reporting chemical and oxygen isotopic analyses of Roman and late Antique glass from northern Greece and chemical, mineralogical, and oxygen isotopic analyses of Greek chert, which revealed particularly interesting to discriminate various raw materials and production technologies and to advance hypothesis on possible local products.

\section{Materials and Methods}

2.1. Materials. In the present study, thirty-nine glass samples were analysed from the isotopic and chemical points of view. Twenty-nine samples come from various archaeological excavations in Thessaloniki. In particular, ten samples come from the Agora area. The age of these samples is generally comprised within the Roman and late Antique periods (1st-6th centuries AD). Their colour varies from colourless to light green, light blue, green/brown, green-blue, and blue (Table 1). The other nineteen samples come from various archaeological excavations in Thessaloniki and their age is comparable with that of the samples from Agora. Their colour is mainly green or greenish, but blue, light yellow, brown, aquamarine, light green, or colourless samples are also selected (Table 1).

The fragmentary state of the Thessaloniki glass samples did not allow typological characterisation, except for those named 1-3, 2-3, 3-3, and 6-3, which were all identified as bottles, and sample 3-4, which is an oil lamp.

In addition to glass from Thessaloniki, a set of ten samples, all typologically identified as pane fragments, comes from the palaeo-Christian church of Maroneia located in the north-easternmost part of Greece. The age of the Maroneia samples ranges from the 4 th to the 6 th centuries $\mathrm{AD}$, and the colours range from colourless to light yellow, light green, green, green-blue, and light blue (Table 1).

Finally, eight samples composed of chert from the quarry in Triadi of Thessaloniki (Central Macedonia, Greece) were selected for isotopic, chemical, and mineralogical analyses. Chert is a hard, dense, cryptocrystalline sedimentary rock, essentially composed of tiny quartz crystals, that is, less than about $30 \mu \mathrm{m}$ in diameter, and may occur as nodular concretions and less commonly as layered formations (bedded chert). Chert is found in both western Greece and the Thessaloniki region (northern Greece) as layers in carbonate and/or magmatic rocks, and chert quarries, dated to prehistoric times, have been found near Thessaloniki. In particular, the above prehistoric chert quarries are located along a steep valley, $2 \mathrm{~km}$ north of the Triadi village, at the foothills of the Chortiatis Mountain (Central Macedonia). The rocks are part of a Mesozoic ophiolite complex and consist mainly of dunites and peridotites, partly serpentinized, as well as gabbros. Extended silicified rocks, comprising mostly chert, occur at the upper part of the dunites and peridotites and below the gabbros. In addition, rare milky-white microcrystalline quartz veins crosscut silicified rocks. The existence of chert formations in Greece would be in favour of their use for glass production and the present paper is also aimed at verifying this hypothesis.
2.2. Methods. Oxygen isotope measurements on glass and chert samples were carried out according to well-established techniques. In order to avoid contamination, glass samples were carefully cleaned prior to analysis. Fragments were crushed in a stainless steel mortar and then finely ground in an agate mortar. Aliquots of about 6-7 $\mathrm{mg}$ of the resulting powder were placed in the nickel vessels of a fluorination line. The samples were then degassed to better than $10^{-3} \mathrm{~mm} \mathrm{Hg}$ for at least one hour and frozen to the temperature of liquid nitrogen; a fivefold stoichiometric amount of $\mathrm{BrF}_{5}$ was introduced into each vessel and the samples were reacted at $600 \pm 10^{\circ} \mathrm{C}$ for about $12 \mathrm{~h}$. The oxygen produced by the reaction was converted to $\mathrm{CO}_{2}$ by cycling over a hollow cylinder of spectrographically pure graphite and inductively heated to about $800^{\circ} \mathrm{C}$ in the presence of a platinum catalyst. $\mathrm{CO}_{2}$ samples were measured for their oxygen isotope ratios in a Finnigan Delta $S$ mass spectrometer versus a laboratory $\mathrm{CO}_{2}$ standard. This standard was prepared by reacting a powdered very pure Carrara marble with $100 \%$ phosphoric acid at $25^{\circ} \mathrm{C}$. Its isotopic values are the following: $+2.45 \%$ o $\left(\delta^{13} \mathrm{C}\right.$ versus VPDB) and $-2.45 \%$ o $\left(\delta^{18} \mathrm{O}\right.$ versus VPDB). Until now we have calibrated our working standard versus NBS-19, the isotopic values of which were taken as $+1.95 \%$ o $\left(\delta^{13} \mathrm{C}\right)$ and $-2.20 \%$ o $\left(\delta^{18} \mathrm{O}\right)$, and versus NBS-20 with isotopic values of $-1.06 \%$ o $\left(\delta^{13} \mathrm{C}\right)$ and $-4.14 \%$ o $\left(\delta^{18} \mathrm{O}\right)$ (the NBS-20 isotopic standard has not been available for many years. We had reasonable quantities of NBS-19 and NBS-20 standards inherited from three Italian universities and three foreign research centres, where A. Longinelli previously worked).

Isotopic results are reported in the usual delta terminology versus the VSMOW isotopic standard, delta being defined as follows:

$$
\delta=\left[\frac{\left(R_{\text {sample }}-R_{\text {standard }}\right)}{R_{\text {standard }}}\right] \times 1000,
$$

where $R$ is the ratio between the heavy and the light isotope, in this case ${ }^{18} \mathrm{O} /{ }^{16} \mathrm{O}$. The delta values were converted from VPDB to VSMOW standard according to the method of Friedman and O'Neil [6].

The reported values are the means of two or more consistent measurements of each sample. The standard deviation of the glass measurements is very good, ranging on average between \pm 0.1 and $\pm 0.2 \%$ o $(2 \sigma)$.

The chemical compositions of glass samples were detected by electron microprobe analysis (EMPA). The instrument used for quantitative analysis of major and minor elements was a CAMECA SX50, equipped with four wavelength-dispersive spectrometers (WDS). The bulk composition of the analysed materials was identified by random point microanalyses (generally 10 per sample), and means and standard deviations were calculated. Standard deviations range from about $0.02 \%$ to about $0.5 \%$, thus proving the homogeneity of the glass fragments; only mean values are reported in the tables. Analysed elements were $\mathrm{Na}, \mathrm{Mg}, \mathrm{Al}, \mathrm{Si}$, $\mathrm{P}, \mathrm{S}, \mathrm{Cl}, \mathrm{K}, \mathrm{Ca}, \mathrm{Ti}, \mathrm{Mn}, \mathrm{Fe}, \mathrm{Sb}, \mathrm{Co}, \mathrm{Ni}, \mathrm{Cu}, \mathrm{Zn}, \mathrm{Sn}$, and Pb. The following standards were employed: synthetic pure oxides for $\mathrm{Mg}, \mathrm{Al}, \mathrm{Fe}$, and $\mathrm{Sn}$, a synthetic MnTi oxide for Mn and Ti, 
TABLE 1: List of analysed glasses from Greece. Colour, age and provenance also shown.

\begin{tabular}{|c|c|c|c|}
\hline $\begin{array}{l}\text { Sample } \\
\text { Number }\end{array}$ & Colour & $\begin{array}{c}\text { Age } \\
\text { Century AD }\end{array}$ & Provenance \\
\hline $1-1$ & Light green & 1st-6th & Agora-Thessaloniki \\
\hline $2-1$ & Green blue & 1st-6th & Agora-Thessaloniki \\
\hline $3-1$ & Colourless & 1 st-6th & Agora-Thessaloniki \\
\hline $4-1$ & Blue & 1 st-6th & Agora-Thessaloniki \\
\hline $5-1$ & Light green & 1st-6th & Agora-Thessaloniki \\
\hline $6-1$ & Colourless & 1st-6th & Agora-Thessaloniki \\
\hline $7-1$ & Green/brown & 1 st-6th & Agora-Thessaloniki \\
\hline $8-1$ & Light green & 1st-6th & Agora-Thessaloniki \\
\hline $9-1$ & Light blue & 1st-6th & Agora-Thessaloniki \\
\hline $10-1$ & Colourless & 1st-6th & Agora-Thessaloniki \\
\hline $1-2$ & Light green & 4th-6th & Maroneia church \\
\hline $2-2$ & Green & 4 th-6th & Maroneia church \\
\hline $3-2$ & Light yellow & 4 th-6th & Maroneia church \\
\hline $4-2$ & Green-blue & 4 th-6th & Maroneia church \\
\hline $5-2$ & Light green & 4 th-6th & Maroneia church \\
\hline $6-2$ & Colourless & 4th-6th & Maroneia church \\
\hline $7-2$ & Light yellow & 4th-6th & Maroneia church \\
\hline $8-2$ & Very light brown & 4 th-6th & Maroneia church \\
\hline $9-2$ & Light blue & 4 th-6th & Maroneia church \\
\hline $10-2$ & Very light green & 4 th-6th & Maroneia church \\
\hline $1-3$ & Light green & 1th-6th & Agora, cryptoporticus-Thessaloniki \\
\hline $2-3$ & Colourless & 1 th-6th & Agora, cryptoporticus-Thessaloniki \\
\hline $3-3$ & Light green & 3 th- 4 th & West cemetery, tomb-Thessaloniki \\
\hline $4-3$ & Green & 1th-6th & School of religion-Thessaloniki \\
\hline $5-3$ & Greenish & 1th-6th & School of religion-Thessaloniki \\
\hline $6-3$ & Colourless & 6 th & Administration building-Thessaloniki \\
\hline $7-3$ & Light yellow & 1th-6th & Administration building-Thessaloniki \\
\hline $3-4$ & Light green & 5 th-6th & landscape of Nastos-Thessaloniki \\
\hline $4-4$ & Greenish & 1 st-6th & Socratous street-Thessaloniki \\
\hline $5-4$ & Greenish & 1st-6th & Socratous street-Thessaloniki \\
\hline $6-4$ & Greenish & 1st-6th & Socratous street-Thessaloniki \\
\hline $7-4$ & Aquamarine & 1st-6th & Socratous street-Thessaloniki \\
\hline $8-4$ & Green & 1 st-6th & Thessaloniki \\
\hline $9-4$ & Colourless & 1st-6th & Thessaloniki \\
\hline $10-4$ & Blue & 1 st-6th & Thessaloniki \\
\hline $11-4$ & Green & 1st-6th & Thessaloniki \\
\hline $12-4$ & Brown & 1st-6th & Thessaloniki \\
\hline $13-4$ & Greenish & 1st-6th & Thessaloniki \\
\hline $14-4$ & Green & 1st-6th & Thessaloniki \\
\hline
\end{tabular}

albite for $\mathrm{Na}$, diopside for $\mathrm{Si}$ and $\mathrm{Ca}$, apatite for $\mathrm{P}$, sphalerite for $\mathrm{Zn}$ and $\mathrm{S}$, vanadinite for $\mathrm{Cl}$, orthoclase for $\mathrm{K}, \mathrm{Sb}_{2} \mathrm{~S}$ for $\mathrm{Sb}$, $\mathrm{PbS}$ for $\mathrm{Pb}$, and pure elements for $\mathrm{Co}, \mathrm{Ni}$, and $\mathrm{Cu}$. Operating conditions were $20 \mathrm{kV}$ and $2 \mathrm{nA}$ sample current, with beam defocused at not less than $10 \mu \mathrm{m}$ for $\mathrm{Na}, \mathrm{K}, \mathrm{Si}$, and $\mathrm{Al}$, in order to minimise the loss of alkali elements and better evaluate $\mathrm{Si}$ contents, and at $20 \mathrm{kV}$ and $30 \mathrm{nA}$ for other elements. X-ray counts were converted to oxide weight percentages with the PAP (CAMECA) correction program. The detailed analytical conditions used and the precision, accuracy, and detection limits of EMPA are given in Silvestri and Marcante [7], as the present samples were subjected to the same analytical protocol. It is stressed here that the precision and accuracy of data were calculated by comparisons with measures on the international reference standard, Corning glass $\mathrm{B}$, in the same analytical conditions as our Greek samples. The precision of EMPA data was generally between $0.5 \%$ and $10 \%$ for major and minor elements, respectively. Accuracy 
TABLE 2: Isotopic and chemical composition of Roman and late Antique glasses from Thessaloniki Agora, 1st-6th century AD in age. Note that $\mathrm{CoO}$ and $\mathrm{NiO}$ contents are not reported because they are lower than EMPA detection limits for all samples $(\mathrm{LOD}$ of $\mathrm{CoO}$ and $\mathrm{NiO}=$ $0.03 \mathrm{wt} \%)$.

\begin{tabular}{|c|c|c|c|c|c|c|c|c|c|c|c|c|c|c|c|c|c|c|}
\hline Sample & $\delta^{18} \mathrm{O}$ & $\mathrm{SiO}_{2}$ & $\mathrm{Na}_{2} \mathrm{O}$ & $\mathrm{CaO}$ & $\mathrm{Al}_{2} \mathrm{O}_{3}$ & $\mathrm{~K}_{2} \mathrm{O}$ & $\mathrm{MgO}$ & $\mathrm{FeO}$ & $\mathrm{TiO}_{2}$ & $\mathrm{MnO}$ & $\mathrm{P}_{2} \mathrm{O}_{5}$ & $\mathrm{SO}_{3}$ & $\mathrm{Cl}$ & $\mathrm{CuO}$ & $\mathrm{ZnO}$ & $\mathrm{SnO}_{2}$ & $\mathrm{Sb}_{2} \mathrm{O}_{3}$ & $\mathrm{PbO}$ \\
\hline Number & (VSMOW) & $\mathrm{Wt} \%$ & Wt\% & Wt\% & Wt\% & $\mathrm{Wt} \%$ & Wt\% & $\mathrm{Wt} \%$ & $\mathrm{Wt} \%$ & $\mathrm{Wt} \%$ & $\mathrm{Wt} \%$ & $\mathrm{Wt} \%$ & Wt\% & $\mathrm{Wt} \%$ & $\mathrm{Wt} \%$ & $\mathrm{Wt} \%$ & $\mathrm{Wt} \%$ & $\mathrm{Wt} \%$ \\
\hline $1-1$ & 15.5 & 66.17 & 16.90 & 8.60 & 2.68 & 0.65 & 1.46 & 1.22 & 0.18 & 1.64 & 0.13 & 0.35 & 0.68 & $<0.03$ & $<0.04$ & $<0.04$ & $<0.04$ & $<0.08$ \\
\hline $2-1$ & 15.6 & 64.65 & 14.96 & 6.14 & 3.16 & 0.94 & 1.49 & 1.11 & 0.20 & 1.48 & 0.65 & 0.16 & 0.65 & 0.67 & 0.04 & 0.89 & $<0.04$ & 2.90 \\
\hline $3-1$ & 15.5 & 71.48 & 15.40 & 7.42 & 2.44 & 0.37 & 0.59 & 0.58 & 0.09 & 0.55 & 0.02 & 0.24 & 0.96 & $<0.03$ & $<0.04$ & $<0.04$ & $<0.04$ & $<0.08$ \\
\hline $4-1$ & 15.6 & 64.24 & 9.88 & 5.74 & 1.59 & 11.47 & 3.48 & 0.30 & 0.03 & $<0.05$ & 1.30 & 0.07 & 0.64 & $<0.03$ & $<0.04$ & $<0.04$ & 0.09 & $<0.08$ \\
\hline $5-1$ & 15.4 & 67.68 & 16.94 & 7.08 & 2.73 & 0.57 & 0.96 & 1.59 & 0.28 & 1.09 & 0.07 & 0.23 & 1.09 & $<0.03$ & $<0.04$ & $<0.04$ & $<0.04$ & $<0.08$ \\
\hline $6-1$ & 15.5 & 72.98 & 17.00 & 4.98 & 2.09 & 0.56 & 0.51 & 0.29 & 0.09 & $<0.05$ & 0.01 & 0.22 & 0.90 & $<0.03$ & $<0.04$ & $<0.04$ & 0.25 & $<0.08$ \\
\hline $7-1$ & 15.6 & 65.43 & 19.76 & 6.54 & 2.38 & 0.40 & 1.08 & 1.14 & 0.26 & 1.12 & 0.02 & 0.27 & 1.60 & 0.14 & $<0.04$ & $<0.04$ & $<0.04$ & 0.33 \\
\hline $8-1$ & 15.5 & 67.14 & 16.83 & 7.86 & 2.92 & 0.91 & 1.29 & 1.65 & 0.20 & 1.45 & 0.26 & 0.25 & 0.54 & $<0.03$ & $<0.04$ & $<0.04$ & $<0.04$ & $<0.08$ \\
\hline $9-1$ & 15.6 & 65.53 & 17.33 & 7.84 & 2.95 & 0.85 & 1.41 & 1.39 & 0.19 & 1.67 & 0.26 & 0.30 & 0.53 & $<0.03$ & $<0.04$ & $<0.04$ & $<0.04$ & $<0.08$ \\
\hline $10-1$ & 15.5 & 76.51 & 9.67 & 8.11 & 0.25 & 3.78 & 1.03 & 0.06 & $<0.04$ & $<0.05$ & 0.06 & 0.40 & 0.19 & $<0.03$ & $<0.04$ & $<0.04$ & $<0.04$ & $<0.08$ \\
\hline
\end{tabular}

was better than $1 \%$ for $\mathrm{SiO}_{2}, \mathrm{Na}_{2} \mathrm{O}$, and $\mathrm{FeO}$, better than $5 \%$ for $\mathrm{CaO}, \mathrm{K}_{2} \mathrm{O}, \mathrm{P}_{2} \mathrm{O}_{5}$, and $\mathrm{Sb}_{2} \mathrm{O}_{3}$, and not worse than $12 \%$ for other major and minor elements.

The chemical and mineralogical compositions of chert samples were obtained by means of X-ray fluorescence (XRF) and X-ray powder diffraction (XRPD), respectively.

$\mathrm{X}$-ray fluorescence (XRF) was carried out on a Philips PW 2400 instrument equipped with a $\mathrm{Rh}$ tube with a rated capacity of $3 \mathrm{~kW}(60 \mathrm{kV} / 125 \mathrm{~mA}$ max.). Three primary collimators $(150,300$, and $700 \mu \mathrm{m}$ spacing) and four analytical crystals (TlAp100, LiF200, Ge111, and PE002) were selected. The spectrometer was interfaced with a personal computer with SuperQ software (Philips). Instrumental parameters and analytical conditions are detailed in Alberta et al. [8]. Geological reference standards were used for calibration [9]. Precision was better than $0.6 \%$ for major and minor elements and about $3 \%$ for trace elements. XRF accuracy was checked by reference standards [9] and was within $0.5 \mathrm{wt} \%$ for $\mathrm{Si}$, lower than 3\% for other major and minor elements, and lower than $5 \%$ for traces. The lowest detection limits of XRF were within $0.02 \mathrm{wt} \%$ for $\mathrm{Al}_{2} \mathrm{O}_{3}, \mathrm{MgO}$, and $\mathrm{Na}_{2} \mathrm{O}$, within $0.4 \mathrm{wt} \%$ for $\mathrm{SiO}_{2}$, and within 0.005 wt $\%$ for $\mathrm{TiO}_{2}, \mathrm{Fe}_{2} \mathrm{O}_{3}, \mathrm{MnO}, \mathrm{CaO}$, $\mathrm{K}_{2} \mathrm{O}$, and $\mathrm{P}_{2} \mathrm{O}_{5}$ and range from 3 to 10 ppm for trace elements. For this type of analysis, chert fragments were crushed in an agate mortar. The resulting powders were heated in an oven at $860^{\circ} \mathrm{C}$ for $20 \mathrm{~min}$. and then at $980^{\circ} \mathrm{C}$ for 2 hours, and the loss on ignition (LOI) was determined. The powders were then mixed with $\mathrm{Li}_{2} \mathrm{~B}_{4} \mathrm{O}_{7}$ at a 1:10 ratio and beads were prepared.

XRPD data were obtained on a computer-controlled Philips X'Pert PRO, with Bragg-Brentano $\theta-\theta$ geometry. The normal-focus $\mathrm{Cu}$ X-ray tube $\left(\mathrm{Cu} \mathrm{K} \alpha_{1} \lambda=0.154056 \mathrm{~nm}\right)$ operated at $40 \mathrm{KV}$ and $20 \mathrm{~mA}$. Data were recorded in the $2^{\circ}-70^{\circ}$ $2 \theta$ range, in step-scan mode with step width increments of $0.02^{\circ}$ and a step counting time of $10 \mathrm{~s}$. Data were processed by the X'Pert HighScore (PANalytical copyright); $2 \theta$ and $d$ values were calculated with the second-derivative algorithm of Savitzky and Golay [10]. All XRPD diffraction profiles were carried out on about $500 \mathrm{mg}$ of samples, finely ground into an agate mortar.
It should be stressed here that XRPD analyses were carried out on all the chert samples, while XRF analyses were carried out only on samples Trd 1-2 and Trd 1-5, which are representative of the two mineralogical compositions identified.

\section{Results and Discussion}

3.1. Results. The ten samples from the Thessaloniki Agora show an extremely homogeneous oxygen isotopic composition (15.4-15.6\%o; Table 2). All the samples from the church of Maroneia, 4th-6th centuries AD in age, also have isotopic compositions ranging from 15.2 to $16.0 \%$, with mean value equal to $15.6 \pm 0.25 \%$ o (Table 3 ). Their mean isotopic values are practically identical to those of the first set of samples from Thessaloniki, although the range of values from Maroneia is slightly larger. The isotopic results obtained on the remaining nineteen glasses from Thessaloniki indicate that only nine samples $(4-3,5-3,7-3,4-4,5-4,6-4,7-4,11-4$, and 14-4) have values very close to those measured in samples from Thessaloniki Agora and Maroneia (Table 4).

In contrast with the remarkable isotopic homogeneity of the majority of Greek glass samples (29/39 samples), chemical compositions are rather heterogeneous (Tables 2, 3, and 4). In particular, samples 1-1, 5-1, 8-1, 9-1 (Table 2), 4-3, 6-4, 114 , and 14-4 (Table 4) from Thessaloniki and all the samples from Maroneia (Table 3) show $\mathrm{SiO}_{2}$ contents ranging from 64.48 to 67.68 wt $\%, \mathrm{Na}_{2} \mathrm{O}$ from 16.36 to 18.46 wt $\%, \mathrm{CaO}$ from 7.02 to $9.07 \mathrm{wt} \%$, and $\mathrm{Al}_{2} \mathrm{O}_{3}$ from 2.29 to $2.92 \mathrm{wt} \%$. $\mathrm{K}_{2} \mathrm{O}$ and $\mathrm{MgO}$ contents are both lower than $1.5 \mathrm{wt} \%$ in all the considered samples, although $\mathrm{MgO}$ is higher than $\mathrm{K}_{2} \mathrm{O}$ $\left(\mathrm{MgO}=1.25 \pm 0.15 \mathrm{wt} \%\right.$ versus $\left.\mathrm{K}_{2} \mathrm{O}=0.70 \pm 0.13 \mathrm{wt} \%\right)$. This group of samples also shows the highest iron, titanium, and manganese contents ( $\mathrm{FeO}$ from 0.80 to $2.12 \mathrm{wt} \% ; \mathrm{TiO}_{2}$ from 0.14 to $0.37 \mathrm{wt} \%$; and $\mathrm{MnO}$ from 0.96 to $2.65 \mathrm{wt} \%$ ) and nondetectable trace elements.

The other glass samples from Thessaloniki (2-1, 3-1, 6-1, $7-1,5-3,7-3,4-4,5-4$, and 7-4), whose $\delta^{18} \mathrm{O}$ is in the range 15.3-15.6\%o (Tables 2 and 4), also show comparable $\mathrm{SiO}_{2}$, 
TABLE 3: Isotopic and chemical composition of glasses from Maroneia, 4th-6th centuries AD in age. Note that $\mathrm{CoO}, \mathrm{NiO}, \mathrm{CuO}, \mathrm{ZnO}, \mathrm{SnO}$, $\mathrm{Sb}_{2} \mathrm{O}_{3}$, and $\mathrm{PbO}$ contents are not reported because they are lower than EMPA detection limits for all samples $(\mathrm{LOD}$ of $\mathrm{CoO}, \mathrm{NiO}$ and $\mathrm{CuO}=$ $0.03 \mathrm{wt} \%$; $\mathrm{LOD}$ of $\mathrm{ZnO}, \mathrm{SnO}_{2}, \mathrm{Sb}_{2} \mathrm{O}_{3}=0.04 \mathrm{wt} \%$; $\mathrm{LOD}$ of $\mathrm{PbO}=0.08 \mathrm{wt} \%$ ).

\begin{tabular}{|c|c|c|c|c|c|c|c|c|c|c|c|c|c|}
\hline $\begin{array}{l}\text { Sample } \\
\text { Number }\end{array}$ & $\begin{array}{c}\delta^{18} \mathrm{O} \\
(\mathrm{VSMOW})\end{array}$ & $\begin{array}{l}\mathrm{SiO}_{2} \\
\mathrm{Wt} \%\end{array}$ & $\begin{array}{l}\mathrm{Na}_{2} \mathrm{O} \\
\mathrm{Wt} \%\end{array}$ & $\begin{array}{l}\mathrm{CaO} \\
\mathrm{Wt} \% \\
\end{array}$ & $\begin{array}{c}\mathrm{Al}_{2} \mathrm{O}_{3} \\
\mathrm{Wt} \%\end{array}$ & $\begin{array}{l}\mathrm{K}_{2} \mathrm{O} \\
\mathrm{Wt} \% \\
\end{array}$ & $\begin{array}{l}\mathrm{MgO} \\
\mathrm{Wt} \%\end{array}$ & $\begin{array}{l}\mathrm{FeO} \\
\mathrm{Wt} \% \\
\end{array}$ & $\begin{array}{l}\mathrm{TiO}_{2} \\
\mathrm{Wt} \% \\
\end{array}$ & $\begin{array}{l}\mathrm{MnO} \\
\mathrm{Wt} \%\end{array}$ & $\begin{array}{l}\mathrm{P}_{2} \mathrm{O}_{5} \\
\mathrm{Wt} \% \\
\end{array}$ & $\begin{array}{l}\mathrm{SO}_{3} \\
\mathrm{Wt} \% \\
\end{array}$ & $\begin{array}{r}\mathrm{Cl} \\
\mathrm{Wt} \% \\
\end{array}$ \\
\hline $1-2$ & 15.4 & 67.11 & 17.39 & 7.84 & 2.29 & 0.61 & 1.10 & 1.06 & 0.15 & 1.54 & 0.07 & 0.30 & 1.02 \\
\hline $2-2$ & 15.5 & 66.23 & 17.80 & 7.83 & 2.70 & 0.76 & 1.23 & 1.33 & 0.17 & 1.23 & 0.15 & 0.31 & 0.92 \\
\hline $3-2$ & 15.6 & 64.62 & 17.70 & 8.98 & 2.40 & 0.72 & 1.47 & 1.04 & 0.16 & 1.82 & 0.12 & 0.34 & 0.92 \\
\hline $4-2$ & 15.9 & 65.64 & 18.46 & 7.95 & 2.70 & 0.82 & 1.21 & 1.38 & 0.16 & 0.96 & 0.13 & 0.32 & 0.91 \\
\hline $5-2$ & 15.6 & 65.70 & 17.38 & 8.25 & 2.38 & 0.59 & 1.21 & 0.88 & 0.15 & 1.69 & 0.09 & 0.34 & 0.95 \\
\hline $6-2$ & 15.6 & 66.79 & 17.17 & 7.50 & 2.53 & 0.60 & 1.25 & 0.98 & 0.16 & 1.84 & 0.08 & 0.30 & 1.00 \\
\hline $7-2$ & 15.7 & 64.63 & 17.96 & 9.07 & 2.57 & 0.71 & 1.50 & 1.10 & 0.18 & 1.72 & 0.13 & 0.33 & 0.92 \\
\hline $8-2$ & 15.2 & 65.56 & 17.56 & 7.52 & 2.50 & 0.65 & 1.25 & 0.93 & 0.17 & 2.34 & 0.09 & 0.29 & 1.01 \\
\hline $9-2$ & 16.0 & 66.13 & 18.14 & 7.83 & 2.73 & 0.84 & 1.22 & 1.28 & 0.15 & 0.99 & 0.16 & 0.34 & 0.90 \\
\hline $10-2$ & 15.3 & 66.59 & 16.36 & 8.59 & 2.40 & 0.69 & 1.11 & 0.88 & 0.17 & 1.60 & 0.11 & 0.36 & 0.87 \\
\hline
\end{tabular}

TABle 4: Isotopic and chemical composition of Roman and late Antique glasses from Thessaloniki, 1st-6th centuries AD in age. Samples with moderate and strong ${ }^{18} \mathrm{O}$ enrichment are in italics and bold font, respectively. Note that $\mathrm{NiO}, \mathrm{ZnO}$, and $\mathrm{SnO}_{2}$ contents are not reported because they are lower than EMPA detection limits for all samples ( $\mathrm{LOD}$ of $\mathrm{NiO}=0.03 \mathrm{wt} \%$; $\mathrm{LOD}$ of $\mathrm{ZnO}$ and $\mathrm{SnO}_{2}=0.04 \mathrm{wt} \%$ ).

\begin{tabular}{|c|c|c|c|c|c|c|c|c|c|c|c|c|c|c|c|c|c|}
\hline 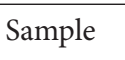 & ${ }^{8} \mathrm{O}$ & $\mathrm{O}_{2}$ & $\mathrm{a}_{2} \mathrm{O}$ & $\mathrm{aO}$ & ${ }_{2} \mathrm{O}_{3}$ & ${ }_{2} \mathrm{O}$ & $\mathrm{MgO}$ & $\mathrm{FeO}$ & $\mathrm{iO}_{2}$ & $\mathrm{InO}$ & $\mathrm{P}_{2} \mathrm{O}_{5}$ & $\mathrm{SO}_{3}$ & $\mathrm{Cl}$ & $\mathrm{CoO}$ & $\mathrm{uO}$ & $\mathrm{Sb}_{2} \mathrm{O}_{3}$ & $\mathrm{bbO}$ \\
\hline Number & JSMOW) & $\mathrm{t} \%$ & $\mathrm{t} \%$ & W & Wt\% & $\mathrm{t} \%$ & $\%$ & $\mathrm{Wt} \%$ & $\mathrm{t} \%$ & $\%$ & $\mathrm{Wt} \%$ & $\mathrm{Wt} \%$ & $\mathrm{Wt} \%$ & $\mathrm{t} \%$ & $\%$ & $\mathrm{Wt} \%$ & $\mathrm{Vt} \%$ \\
\hline 3 & .6 & 46 & & & & 4.85 & & 0.58 & 6 & & 9 & 7 & 1.28 & & 3 & & $<0.08$ \\
\hline-3 & 22.5 & 7.31 & & 9.80 & & 77 & 2 & 57 & 0.05 & 6 & 66 & 07 & 1.29 & 03 & .03 & 0.04 & 0.08 \\
\hline 3 & 6 & .95 & 46 & $6 ?-2+3$ & & 13 & 96 & 0.63 & 0.10 & 27 & 0 & 0.25 & 1.43 & & .03 & $<0.04$ & 0.08 \\
\hline 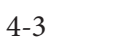 & & 20 & 7 & 7.02 & & 0 & 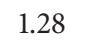 & 2 & 0.37 & 5 & 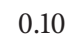 & 0 & 1.23 & & 03 & 4 & $<0.08$ \\
\hline & & 39 & 7 & s & 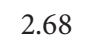 & 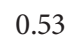 & 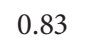 & 1 & 7 & - & 7 & 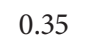 & 1.19 & & 03 & 4 & $<0.08$ \\
\hline & & & & & & & & & 0.11 & & & & 0.87 & & & & $<0.08$ \\
\hline 7-3 & 15.2 & 71.02 & 15.53 & 0.47 & 2.00 & 0.03 & 0.42 & 0.20 & 0.04 & $0 . J 3$ & 0.09 & 0.05 & 1.06 & $<0.03$ & $<0.03$ & $<0.04$ & $<0.08$ \\
\hline $3-4$ & 16.1 & 4.78 & 18.62 & 7.75 & 2.37 & 0.59 & 1.19 & 1.15 & 0.15 & 1.52 & 0.05 & 0.44 & 0.93 & $<0.03$ & $<0.03$ & $<0.04$ & $<0.08$ \\
\hline-4 & 15.3 & 67.32 & 16.96 & 7.85 & 2.52 & 0.31 & 0.88 & 0.72 & 0.22 & 1.61 & 0.01 & 0.28 & 1.36 & $<0.03$ & $<0.03$ & $<0.04$ & $<0.08$ \\
\hline & 3 & .78 & 96 & 6.52 & 40 & 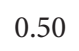 & 0.95 & 0.7 & 0.21 & 1.66 & 2 & 0 & 1.19 & 3 & 03 & $<0.04$ & $<0.08$ \\
\hline & & 5 & 46 & & & 0.62 & 1.00 & 0.80 & 0 & 1.92 & 5 & 0 & 0.99 & 3 & 03 & & $<0.08$ \\
\hline $7-4$ & & 80 & 6 & 0 & & 0. & 0.87 & 0 & 0.10 & 0.77 & 4 & 0.31 & 1.46 & & 0 & $<0.04$ & $<0.08$ \\
\hline $8-4$ & & 56 & & 3 & & & & 0 & 0.17 & & & 0.14 & 0.88 & & 03 & & 0.50 \\
\hline $9-4$ & .7 & 80 & 9.80 & & & 5.45 & 2.35 & 0.51 & 0.05 & 0.67 & 0.52 & 0.10 & 0.91 & $<\mathbf{0 . 0 3}$ & .03 & 4 & $<0.08$ \\
\hline & .4 & 46 & 19.83 & 6.36 & & 0.49 & 1.1 & 1. & 0.16 & & 1 & 2 & 1.23 & & 21 & $<0$ & 0.63 \\
\hline & & 64.51 & & & & 0.70 & & 1.45 & 0.14 & & & 0.70 & 0.98 & & $<0.03$ & & $<0.08$ \\
\hline $12-7$ & 20.5 & 62.72 & 11.79 & 9.45 & 1.34 & 4.40 & 2.04 & 0.92 & 0.06 & 4.38 & 0.39 & 0.13 & 1.05 & $<\mathbf{0 . 0 3}$ & $<\mathbf{0 . 0 3}$ & 0.06 & $<0.08$ \\
\hline $13-4$ & 17.3 & 64.44 & 12.68 & 9.6 & 2.34 & 4.23 & 2.07 & 0.76 & 0.12 & 1.21 & 0.42 & 0.16 & 1.01 & $<0.03$ & $<0.03$ & 0.04 & 0.14 \\
\hline $4-4$ & 15.6 & 4.48 & 17.81 & 23 & 2.58 & 0.79 & 1.34 & 1.97 & 0.15 & 1.15 & 0.14 & 0.54 & 0.98 & $<0.03$ & $<0.03$ & $<0.04$ & $<0.08$ \\
\hline
\end{tabular}

$\mathrm{Na}_{2} \mathrm{O}, \mathrm{CaO}, \mathrm{K}_{2} \mathrm{O}$, and $\mathrm{MgO}$ contents with the previous glass samples, although they differ in contents of colouring/decolouring elements, for example, iron, copper, manganese, and antimony and minor elements, for example, tin and lead (Tables 2 and 4). In particular, samples 5-3, 4-4, and 5-4 show concentrations of manganese higher than $1 \mathrm{wt} \%$, whereas sample 6-1 has no manganese but antimony (Table 2). Instead, samples 3-1 and 7-3 do not reveal any manganese or antimony (Tables 2 and 4). Sample 2-1 from Thessaloniki Agora has relatively high concentrations of $\mathrm{CuO}, \mathrm{SnO}_{2}, \mathrm{PbO}$, and $\mathrm{P}_{2} \mathrm{O}_{5}$ (Table 2). The chemical composition of sample 7-1 is comparable with that of sample 2-1, except for the lower copper and lead contents (Table 2). Lastly, samples 41 and 10-1 from Thessaloniki Agora, which have comparable $\delta^{18} \mathrm{O}$ values, show chemical compositions different from each other, except for the similar (and relatively low) content of sodium (about $10 \mathrm{wt} \% \mathrm{Na}_{2} \mathrm{O}$ ) and the absence of manganese and trace elements in both samples. In particular, sample 4-1 has lower $\mathrm{SiO}_{2}$ and $\mathrm{CaO}$ and higher $\mathrm{Al}_{2} \mathrm{O}_{3}, \mathrm{~K}_{2} \mathrm{O}, \mathrm{MgO}, \mathrm{FeO}$, $\mathrm{P}_{2} \mathrm{O}_{5}$, and $\mathrm{Cl}$ than sample 10-1 (Table 2). 
TABLE 5: $\delta^{18} \mathrm{O}_{\text {(VSMOW) }}$ of chert samples from the quarries in Triadi of Thessaloniki (Central Macedonia, Greece).

\begin{tabular}{llrc}
\hline Samples & \multicolumn{2}{c}{$\delta^{18} \mathrm{O}_{(\text {VSMOW })}$} & Mean \\
\hline Trd 1-1 & 25.0 & 25.1 & 25.0 \\
Trd 1-2 & 23.4 & 23.5 & 23.4 \\
Trd 1-4 & 23.6 & 23.8 & 23.7 \\
Trd 1-5 & 26.0 & 26.1 & 26.0 \\
Trd 2-1 & 24.2 & 24.4 & 24.3 \\
Trd 3-1 & 26.1 & 26.0 & 26.0 \\
Trd 3-2 & 25.8 & 26.0 & 25.9 \\
Trd 5-2 & 22.5 & 22.3 & 22.4 \\
\hline \multicolumn{4}{c}{} \\
\hline
\end{tabular}

Lastly, sample 8-4 from Thessaloniki, with $\delta^{18} \mathrm{O}$ equal to $15.6 \%$, is characterised by lower silicium and sodium contents and higher calcium, aluminium, potassium, magnesium, and phosphorous contents (Table 4) than other glasses with comparable isotopic composition.

In addition to samples with isotopic signatures ranging from 15.2 to $16.0 \%$, the isotopic data indicate that four samples from Thessaloniki are heavily enriched by about $7 \%$ : sample $12-4$ has $\delta^{18} \mathrm{O}$ equal to $20.5 \%$, and samples $1-3,2-3$, and $9-4$ have values from 22.5 to $22.7 \%$. Finally, other five samples from Thessaloniki (3-3, 6-3, 3-4, 10-4, and 13-4) show moderate ${ }^{18} \mathrm{O}$ enrichment, with values between 16.1 and $18.6 \%$ o (Table 4).

The chemical analyses of the heavily enriched glass (Table 4) show that all samples are characterised by higher $\mathrm{CaO}, \mathrm{K}_{2} \mathrm{O}, \mathrm{MgO}$, and $\mathrm{P}_{2} \mathrm{O}_{5}$ and lower $\mathrm{Na}_{2} \mathrm{O}$ and $\mathrm{Al}_{2} \mathrm{O}_{3}$ contents than other Greek samples with lower isotopic composition. In addition, sample $12-4$ also has exceptionally high manganese $(\mathrm{MnO}=4.38 \mathrm{wt} \%$, Table 4$)$.

The samples with moderate ${ }^{18} \mathrm{O}$ enrichment show quite variable chemical compositions but comparable to those of samples with lower and higher isotopic compositions. Samples 3-3 $\left(\delta^{18} \mathrm{O}=18.6 \%\right)$ and $10-4\left(\delta^{18} \mathrm{O}=16.4 \% 0\right)$ have chemical compositions comparable to those of samples 5-3, 4-4, and 5-4, although sample 10-4 has very little $\mathrm{Mn}$ and high $\mathrm{Cu}$ and $\mathrm{Pb}$ (Table 4). Sample 6-3 $\left(\delta^{18} \mathrm{O}=17.3 \%\right)$ is similar in chemical composition to samples 1-1, 5-1, 8-1, 9.1, 4-3, 64, 11-4, and 14-4 from Thessaloniki (Tables 2 and 4) and all the samples from Maroneia (Table 3). Finally, the chemical composition of sample $13-4\left(\delta^{18} \mathrm{O}=17.3 \%\right.$ ) is very similar to those of the heavily enriched glass, as deduced from its low $\mathrm{Na}_{2} \mathrm{O}$ and $\mathrm{Al}_{2} \mathrm{O}_{3}$ and high $\mathrm{CaO}, \mathrm{K}_{2} \mathrm{O}, \mathrm{MgO}$, and $\mathrm{P}_{2} \mathrm{O}_{5}$ contents (Table 4).

The isotopic data obtained on the chert samples from the quarries in Triadi of Thessaloniki show that mean $\delta^{18} \mathrm{O}$ value (equal to $24.6 \pm 1.4 \%$, Table 5) is comparable to those of Greek glass samples heavily enriched $\left(\right.$ mean $\delta^{18} \mathrm{O}$ value $=$ $22.1 \pm 1.1 \%$ ). Mineralogical data, obtained by means of XRPD, show chert samples are a mixture of quartz and goethite (semiquantitative contents of the two phases: $94 \%$ quartz and 6\% goethite), except for sample Trd 1-5 composed of only quartz (Figure 1).
XRF data furtherly confirm the mineralogical compositions, sample Trd 1-2 being almost entirely composed of $\mathrm{SiO}_{2}$ and $\mathrm{Fe}_{2} \mathrm{O}_{3}$ and Trd 1-5 of only $\mathrm{SiO}_{2}$ (Table 6).

3.2. Discussion. The majority of the analysed samples from Thessaloniki and all the samples from Maroneia have a homogeneous oxygen isotopic composition $\left(\delta^{18} \mathrm{O}\right.$ value $=$ $15.6 \pm 0.25 \%$, Table 2 and Figure 2), which is equal or very close to the mean value of "Roman" glass, as deduced from a set of isotopic measurements on glass from Europe dated from the 1st to the 4th centuries $\mathrm{AD}$, which show a relatively narrow range of $\delta^{18} \mathrm{O}$ (from about $15.4 \%$ to $16.0 \%$ ) $[2,3]$. Similar results (Figure 2) were also obtained for late Antique/early Medieval samples from Grado and Vicenza, two sites in Northern Italy [3] and for coeval glass from the Near East [11, 12].

These similarities may be explained by assuming that the Greek glass samples were produced with raw materials with equal or very similar oxygen isotopic composition. Sand from the rivers Belus in Palestine and Volturno in Italy, mentioned by Pliny the Elder in Naturalis Historia as materials for making glass, is suitable for glass production and has the same oxygen isotopic composition, when the Volturno sand undergoes selective grinding [3]. It follows that glass produced with either Belus or Volturno sand as network former and natron as flux is practically indistinguishable from the oxygen isotopic point of view. Consequently, the isotopic composition of most of the Greek samples in Tables 2,3 , and 4 cannot help to distinguish among glass samples imported from Italy or the Near East or glass samples produced in Greek secondary glass workshops by melting raw glass: from the geographic point of view, a Levantine origin for the Greek glass samples is quite reasonable. This origin is reinforced by data reported in Brill [13] on five cullets from an ancient glass workshop at Jalame in western Galilee (3rd4 th centuries $\mathrm{AD}$ ). The author suggests that the silica used for these cullets came from sand taken from the mouth of the Belus and that the oxygen isotopic composition of quartz was enriched in ${ }^{18} \mathrm{O}$ by the calcium carbonate contained in the sand in the form of sea shells, with natron as flux. The $\delta^{18} \mathrm{O}$ values of the Jalame glass are slightly lower than those of Greek samples and range from about 14 to $15 \%$ (Figure 2). Although the use of various other raw materials cannot be completely excluded, this small difference may be explained by amounts of natron used for melting which are slightly smaller in Jalame than in Greek glass samples. The oxygen isotopic study carried out by Silvestri et al. [3] on Roman natron glass demonstrated the "positive natron effect"; that is, it is presumed that flux, which has very positive $\delta^{18} \mathrm{O}$ values, caused ${ }^{18} \mathrm{O}$ enrichment in the final glass, as confirmed by the plot of $\mathrm{Na}_{2} \mathrm{O}$ versus $\delta^{18} \mathrm{O}$, which clearly shows a positive correlation. Other glass samples from the Near East have $\delta^{18} \mathrm{O}$ values close to those of our samples, showing "Roman" values (Figure 2). These samples, measured by Leslie et al. [12], came from different locations: three from the Beth Shean in Israel (6th-7th centuries AD), mean value 14.6\%; three from Tel el-Ashmunein in Egypt (8th-9th centuries), mean value $14.8 \%$; and three from Carthage in Tunisia 

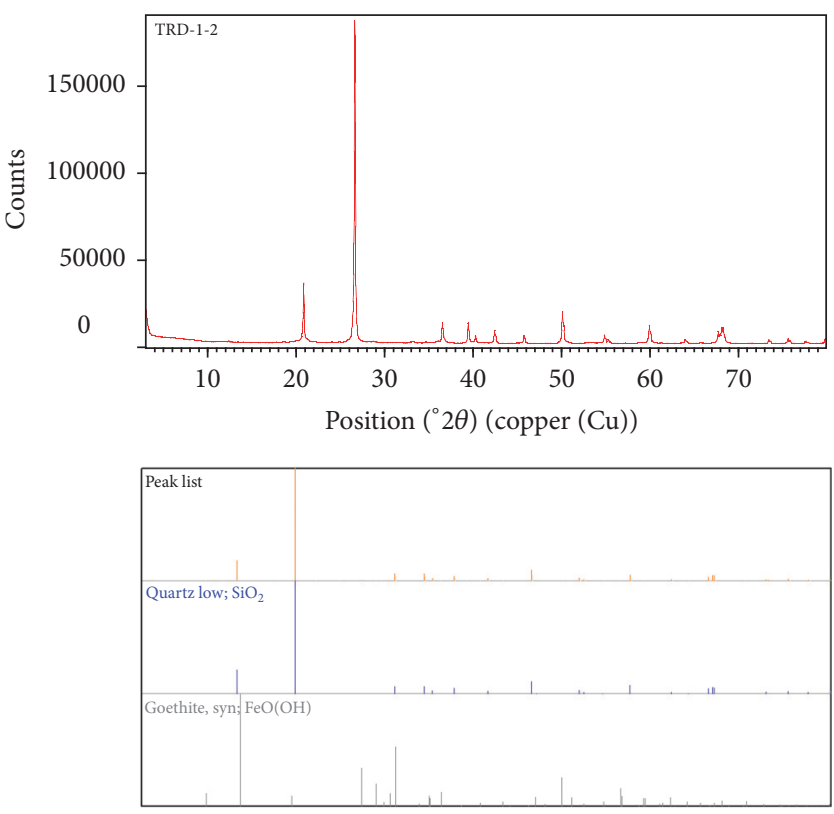

(a)
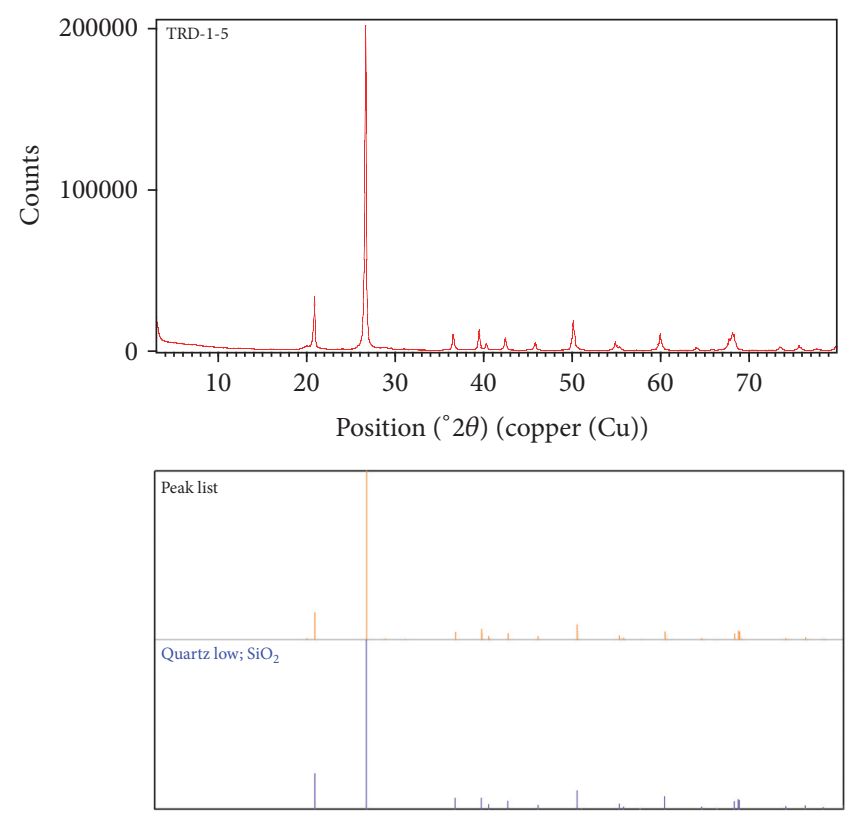

(b)

FIGURE 1: XRPD patterns of chert samples, named Trd 1-2 (a) and Trd 1-5 (b), representative of the two mineralogical compositions identified.

(4th-6th centuries), mean value $15.0 \%$. All these samples are obtained using natron from the evaporitic lakes of Wadi Natron in Egypt. The provenance of sand from a relatively short stretch of the eastern Mediterranean coast is suggested for the Beth Shean samples, and the similarity between the delta values of the Tel el-Ashmunein and Carthage samples is explained by their production with the same Egyptian sand. The isotopic similarity among these three groups of samples can be explained taking into account a common provenance for natron and that Levantine sand comes from Egypt and is transported up to the eastern Mediterranean coast by sea currents $[14,15]$; therefore the use of sand and flux with similar provenance yields glass samples with similar isotopic compositions. The same source may thus be hypothesised for the Greek glass samples analysed here. However, it should be stressed that natural natron deposits in the region of Macedonia in northern Greece were wellknown in the time of Plato (5th century BC) and were also described by Pliny the Elder in his Naturalis Historiae. Hatzopoulos and Loukopoulou [16] identified Lake Chalastra (so-called in antiquity, that is, the place where the "Chalastraion nitron" formed and dissolved over a period of a few days) as the modern lake of Picrolimni, located about $20 \mathrm{~km} \mathrm{NW}$ of Thessaloniki. The geochemical conditions responsible for the formation of "Chalastraion nitron" have recently been studied and discussed by Dotsika et al. [17]. The salts deposited by the lake brine were mineralogically identified by XRD analysis and include not only calcite and dolomite, but also trona $\left(\mathrm{Na}_{2} \mathrm{CO}_{3} \cdot \mathrm{NaHCO}_{3} \cdot 2 \mathrm{H}_{2} \mathrm{O}\right)$, burkeite $\left(\mathrm{Na}_{2} \mathrm{CO}_{3} \cdot 2 \mathrm{Na}_{2} \mathrm{SO}_{4}\right)$, and halite $(\mathrm{NaCl})$, thus confirming the mineralogical similarity between these deposits and those from Wadi Natron in Egypt. However, the oxygen isotopic compositions determined on the Picrolimni salt deposits range from about 11 to $25 \%$ (VSMOW), much lower than the values for Wadi Natron (about 34 to 40\%o [2,3]). Therefore, in the case of our samples, use of "Chalastraion nitron" as flux can hardly be considered.

In contrast with the remarkable isotopic homogeneity of the majority of Greek samples (29/39 samples), the chemical composition is rather heterogeneous (Tables 2, 3, and 4), although they are all obtained with natron as flux, having both $\mathrm{K}_{2} \mathrm{O}$ and $\mathrm{MgO}$ contents lower than $1.5 \mathrm{wt} \%$. In particular, samples 1-1, 5-1, 8-1, 9-1, 4-3, 6-4, 11-4, and 14-4 from Thessaloniki (Tables 2 and 4) and all the samples from Maroneia (Table 3) show the HIMT (High Iron, Magnesium, and Titanium) signature. This reference group is defined by high levels of iron ( $\geq 0.7 \mathrm{wt} \%$ ), manganese (usually $\sim 1-2 \mathrm{wt} \%$ ), magnesium (usually $\geq 0.8 \mathrm{wt} \%$ ), and titanium ( $\geq 0.1 \mathrm{wt} \%$ ), and its yellow-green colour is due to the amount of iron, suggestive of a relatively impure sand source [18]. These also are the key characteristics of Greek glass samples, which have high $\mathrm{FeO}(1.20 \pm 0.31 \mathrm{wt} \%), \mathrm{MnO}(1.54 \pm 0.35 \mathrm{wt} \%), \mathrm{MgO}(1.24 \pm$ $0.16 \mathrm{wt} \%)$, and $\mathrm{TiO}_{2}(0.18 \pm 0.05 \mathrm{wt} \%)$ contents. The acronym HIMT was first applied by Freestone [19] to raw glass from Carthage and glass vessels from Cyprus [20], although glass with high contents of iron, manganese, and titanium was already identified by Sanderson et al. [21]. However, all the Greek samples (except 4-3), containing about $50-60 \%$ of the amount of iron, titanium, and manganese oxides measured in "typical" HIMT glass, such as Group 1 of Foy et al. [22] (about $1.21 \pm 0.31 \mathrm{wt} \%$ as $\mathrm{FeO}, 0.17 \pm 0.03 \mathrm{wt} \%$ as $\mathrm{TiO}_{2}$, and $1.51 \pm 0.37 \mathrm{wt} \%$ as $\mathrm{MnO}$ versus $2 \pm 0.8 \mathrm{wt} \%$ as $\mathrm{FeO}$, $0.5 \pm 0.1 \mathrm{wt} \%$ as $\mathrm{TiO}_{2}$, and $2.2 \pm 0.4 \mathrm{wt} \%$ as $\mathrm{MnO}$ for Greek samples and Group 1, resp.), show a better fit with "Group 2" of Foy et al. [22], which may be considered as a "weak" HIMT glass [18], due to lower contents of the key oxides of HIMT 


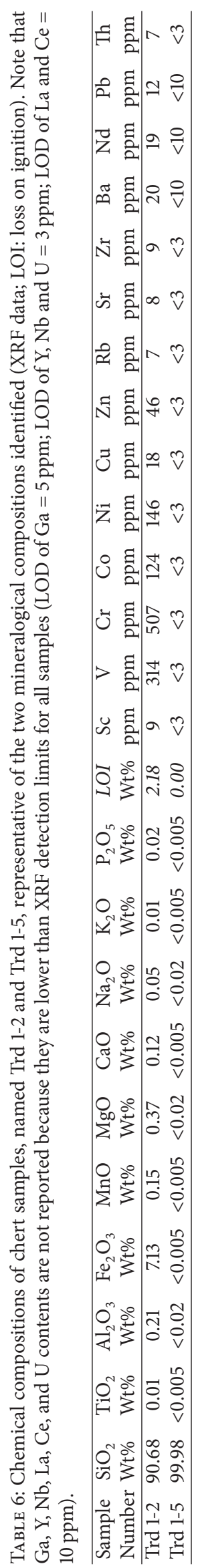




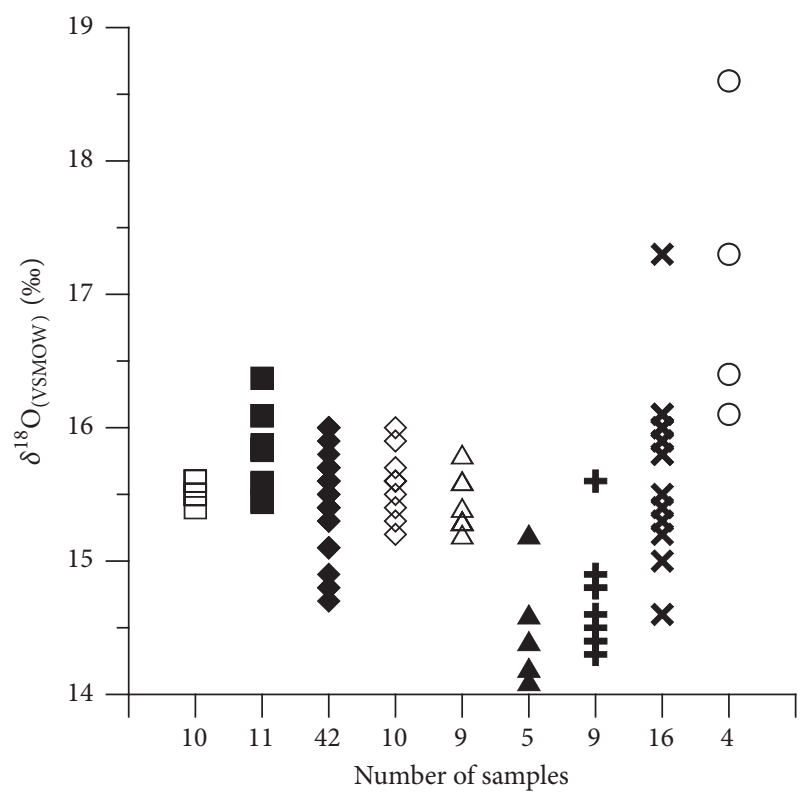

FIgURE 2: Comparisons among $\delta^{18} \mathrm{O}_{\text {(VSMOW) }}$ values of natron glass samples [open symbols: Thessaloniki Agora $(\square)$; Maroneia $(\diamond)$; Thessaloniki, various sites $(\triangle)$; Thessaloniki glass with moderate ${ }^{18} \mathrm{O}$ enrichment $(\mathrm{O})$ ] and those already reported in the literature [full symbols: Roman glass from Europe (घ) [2]; Roman glass from Iulia Felix $(\diamond)$ [3]; 4th century AD glass from Jalame (ム) [2]; HIMT glass from Carthage and Levantine natron glass (bold plus sign) [12]; late Antique-early Medieval glass from Grado ad Vicenza (bold multiplication sign) [3]]. Number of analysed samples is also shown.

glass (Figure 3). Instead, sample 4-3 has $\mathrm{FeO}, \mathrm{TiO}_{2}$, and $\mathrm{MnO}$ contents (Table 4 ) perfectly comparable with "typical" HIMT glass $[18,22]$. In general, HIMT glass has also been identified in Britain [18], Egypt [23], France [22], Italy [2429], Cyprus [20,30], Carthage [31], Bulgaria [32], and Albania [33]. The chemical and isotopic signatures of HIMT glass are suggestive of continental sand sources of high maturity, rich in heavy minerals and located in the Near East, probably in Egypt $[12,31,34]$. As regards the dating of the reference groups, in general terms the HIMT group is probably more characteristic of the period from the mid-4th century AD onwards, although according to current research its composition seems to have continued after the 5th century [18]. In addition, according to Schibille et al. [31], "Group 2" is dated to the 5th-6th centuries and is thus coeval with the glass from Maroneia. Consequently, the age of Thessaloniki glass samples, similar in composition to those of "Group 2," is constrained to the late Antique period.

The other glass samples from Thessaloniki (2-1, 3-1, 6-1, $7-1,5-3,7-3,4-4,5-4$, and 7-4), whose $\delta^{18} \mathrm{O}$ is in the range of "Roman" values, also show the chemical composition typical of Roman glass [35], although they differ in contents of manganese and antimony (Figure 3) and trace elements. In particular, samples 3-1, 5-3, 4-4, and 5-4 show $\mathrm{MnO}>0.5 \mathrm{wt} \%$, which suggests its intentional addition as a decolouriser [36], whereas sample 6-1 has no manganese but antimony (Table 2). As these two elements, the principal decolourisers used between the 1st and 4th centuries $\mathrm{AD}$, were both predominant from the late 1st to the 3 rd centuries and as the use of manganese increased from the end of the $3 r d$ to the 4th century [36-38], the age of these samples is constrained accordingly. Instead, samples 3-1 and 7-3 do not reveal any intentional addition of decolouriser, having no antimony and $\mathrm{MnO}<0.5 \mathrm{wt} \%$ (Tables 2 and 4). Sample 2-1 from Thessaloniki Agora has relatively high concentrations of $\mathrm{CuO}, \mathrm{SnO}_{2}, \mathrm{PbO}$, and $\mathrm{P}_{2} \mathrm{O}_{5}$ (Table 2), suggesting the inclusion of cullet, perhaps coloured and opaque mosaic tesserae containing high quantities of one or more of these elements, in the glass batch. The chemical composition of sample 7-1 is not far from that of sample 2-1, although the concentrations of copper and lead are much lower than those in sample 2-1 (Table 2). This indicates that the presence of the above elements is due to recycling of earlier coloured glass, because they occur in concentrations higher than those attributable to impurities in the raw materials but too low to have any technological significance [39]. Conversely, the high $\mathrm{Cu}$ in sample 7-4, not associated with high $\mathrm{Sn}, \mathrm{Co}, \mathrm{Pb}, \mathrm{Sb}$, and $\mathrm{Zn}$ (Table 4), suggests that this element was intentionally added to produce the aquamarine colour.

Lastly, chemical similarities between samples 4-1 and 10-1 from Thessaloniki Agora and data reported in the literature are difficult to establish. Sample 4-1 seems quite comparable with some soda-potash-lime glass from the 14th-century workshop at Saint-Chély (France). Two different hypotheses, both equally valid from an analytical point of view, are proposed to explain the peculiar chemical composition of these Late Medieval French samples [40]: both soda and potash ash were used by the glass-workers, soda ash remaining the main component; recycled glass from the surrounding areas, with both potash and soda ash compositions, was used as raw materials. Sample 10-1 also approaches, although not perfectly, the composition of "mixed soda-potash glass" dated to Late Bronze age [40] and the oxygen isotopic data obtained by Brill et al. [2] on some Late Bronze age objects are also quite comparable with that of sample 10-1. On the contrary, oxygen isotope data on samples with chemical composition similar to sample 4-1 are unfortunately still lacking, although data on Medieval soda ash and late Medieval and modern potash ash glass are systematically lower and range from about 12 to $14.5 \%$ o $[2,3]$. In any case, both isotopic and chemical data suggest that the age proposed for samples 4-1 and 10-1 from Thessaloniki Agora should be revised.

The chemical analyses of the heavily enriched glass (Table 4) show that all samples were melted with soda ash as flux, their $\mathrm{K}_{2} \mathrm{O}, \mathrm{MgO}$, and $\mathrm{P}_{2} \mathrm{O}_{5}$ contents being higher than those of the other samples (Figure 3). The low $\mathrm{Al}_{2} \mathrm{O}_{3}$ content suggests that, as well as flux, a different silica source was used to produce these samples. Leslie et al. [12] report some highly variable isotopic results from glass samples, 10th-13th centuries in age, from Ra's al-Hadd (Oman), one of which is close to $20 \%$ (Figure 4). Heavily enriched $\delta^{18} \mathrm{O}$ values which range from 21.6 to $22.6 \%$ have already been measured by Brill et al. [2] on glass samples from Nimrud (Iraq) dated to the 7th century BC; the author obviously concluded that "these glasses must represent a glassmaking 


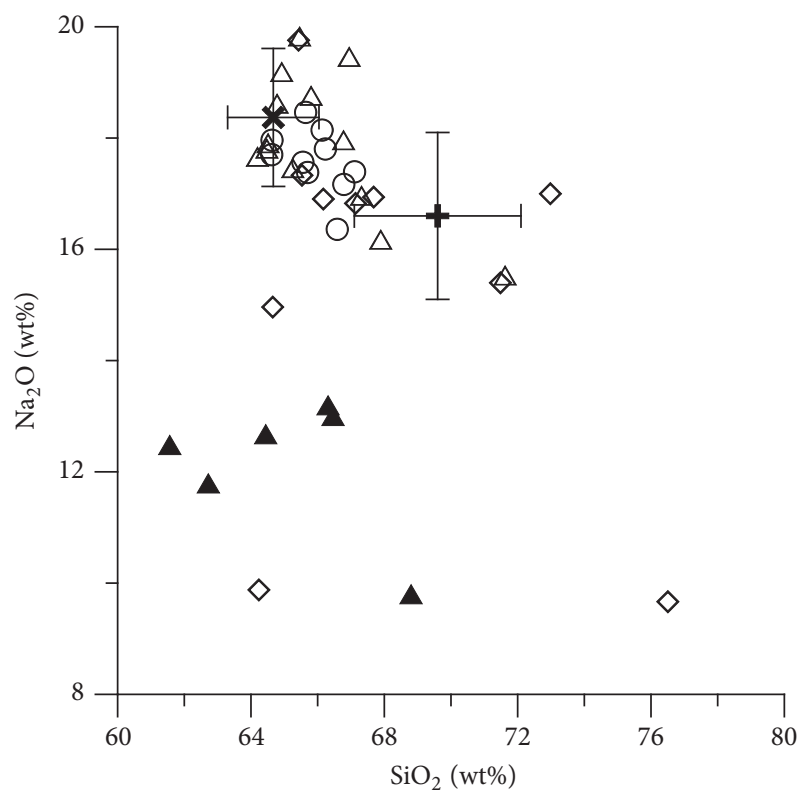

(a)

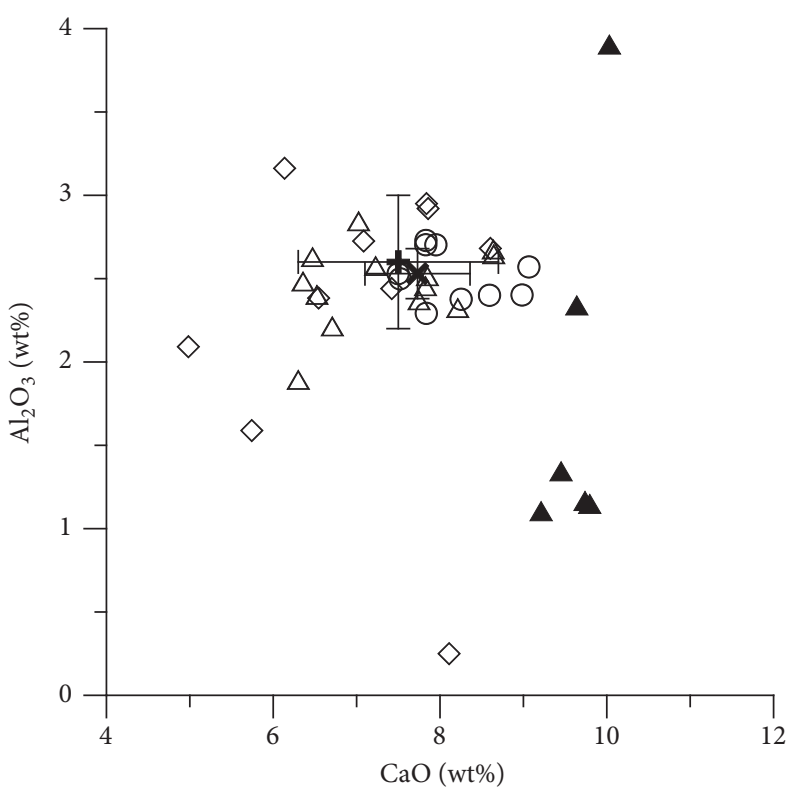

(c)

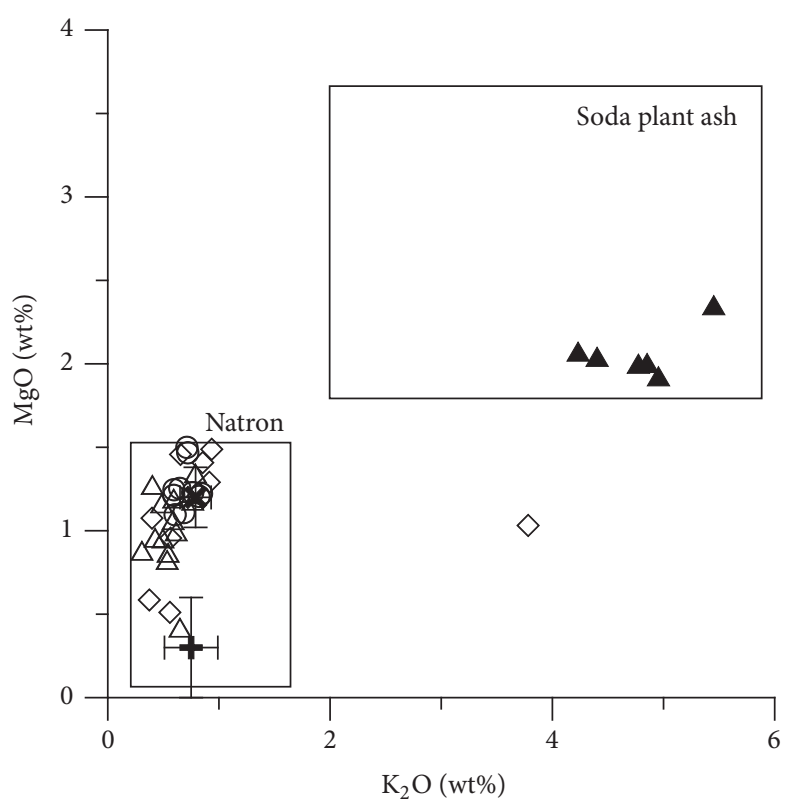

(b)

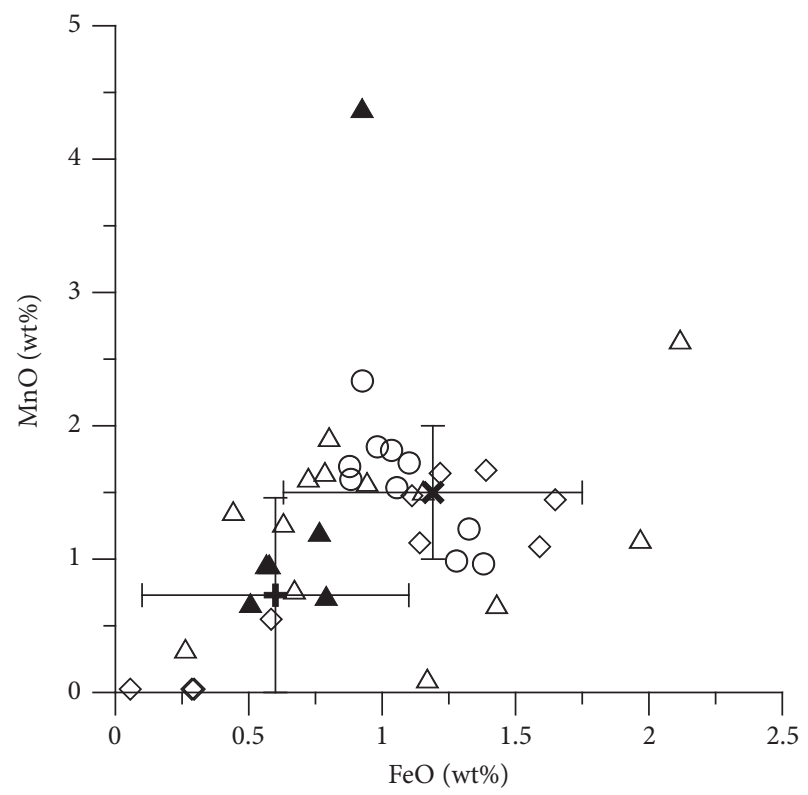

(d)

Figure 3: $\mathrm{Na}_{2} \mathrm{O}$ versus $\mathrm{SiO}_{2}$ (a), $\mathrm{MgO}$ versus $\mathrm{K}_{2} \mathrm{O}$ (b), $\mathrm{Al}_{2} \mathrm{O}_{3}$ versus $\mathrm{CaO}$ (c), and $\mathrm{MnO}$ versus $\mathrm{FeO}$ (d) contents of Greek glass samples, subdivided by provenance: Thessaloniki Agora $(\diamond)$, Maroneia $(O)$, Thessaloniki, various sites $(\triangle$ : natron glass; $\mathbf{\Delta}$ : soda ash glass). Mean chemical compositions and standard deviations of main compositional natron groups, identified in literature and comparable with Greek samples, are also shown: "Roman" glass (bold plus sign), Group 2 (bold multiplication sign) [22, 35].

tradition that made use of some particular raw material." Two samples from Aphrodisias (Turkey), 6th-7th centuries AD in age, also yielded $\delta^{18} \mathrm{O}$ values of about $23.4 \%$ (Figure 4 ). All the samples reported in the literature with very positive $\delta^{18} \mathrm{O}$ values were obtained with soda ash as flux, although they show lower $\mathrm{K}_{2} \mathrm{O} / \mathrm{MgO}$ and higher $\mathrm{Na}_{2} \mathrm{O} / \mathrm{K}_{2} \mathrm{O}$ ratios than Greek samples, suggesting the use of different kinds of plant ash.
In Europe and Mediterranean area soda ash glass dates from the 9th century $\mathrm{AD}$ onwards [4, 41]. This would exclude a Roman age for Greek soda ash samples, unless they were produced with raw glass imported from areas, such as Mesopotamia and Iran, where plant ash continued to be used as flux in glass production throughout the period of natron dominance in the West [4]. However, so far, chemical comparisons with 3 rd-7th-century soda ash glass from Iraq 


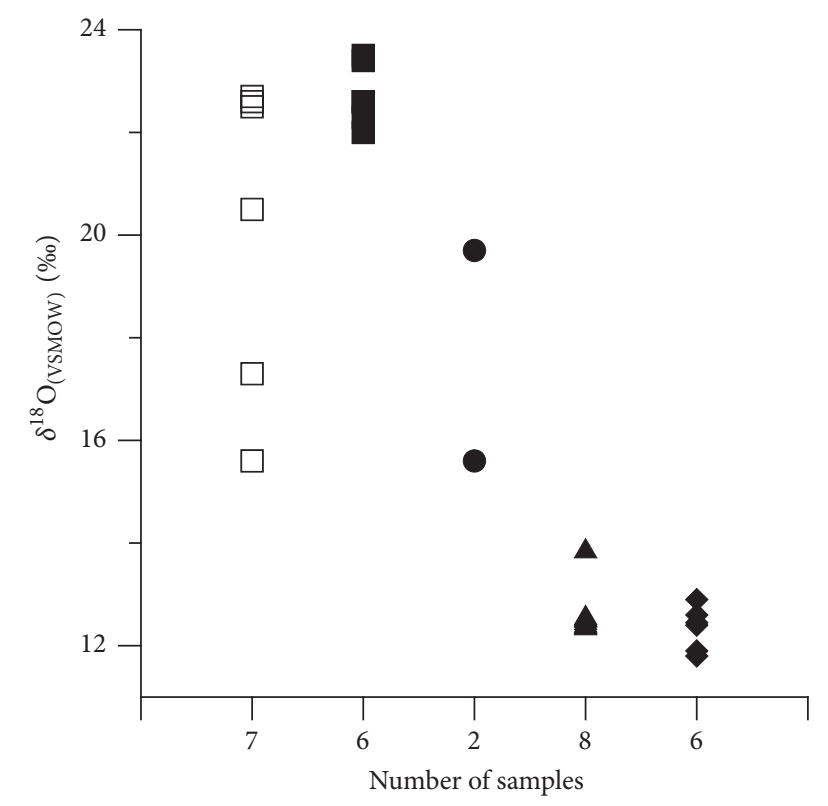

FIGURE 4: Comparisons among $\delta^{18} \mathrm{O}_{\text {(VSMOW) }}$ values of plant ash glass samples [open symbols: Thessaloniki, various sites $(\square)$ ] and those already reported in the literature [full symbols: glass from Nimrud

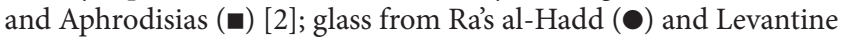
soda ash glass $(\diamond)$ [12]; Medieval soda ash glass from Italy (४) [3]]. Number of analysed samples is also shown.

$[42,43]$ have not shown any consistency with Greek samples. In addition, the heavily enriched $\delta^{18} \mathrm{O}$ values do indicate that their raw materials differed from those normally used in Roman and Medieval glass production, and this would match the possibility of the different origin of these materials. The use of ash as flux may cause some ${ }^{18} \mathrm{O}$ enrichment when the ash is particularly rich in carbonate, bicarbonate, and hydrate [4] but hardly to this extent. Previous oxygen isotopic data, obtained on Medieval soda ash glass from the Western and Eastern Mediterranean (Figure 4), indicate that the addition of ash did not contribute to isotopically heavy oxygen and the $\delta^{18} \mathrm{O}$ values essentially reflect the silica source (e.g., $[2,3,12]$ ). In the case of Greek heavily enriched glass the silica source is difficult to identify, taking into account the fact that quartz, with anomalously heavy isotopic composition, is uncommon in magmatic, sedimentary, or metamorphic rocks. Due to the large oxygen isotopic fractionation between $\mathrm{SiO}_{2}$ and water at low temperatures, biogenic silica and chert have the highest ${ }^{18} \mathrm{O} /{ }^{16} \mathrm{O}$ ratios observed in rocks [44]. Therefore, the Greek samples with high isotopic values may be the product of local glass workshops which used raw materials, composed of chert, with the addition of ash, probably obtained from various plant species other than those considered by Tite et al. [4] or differently pretreated. The isotopic, chemical, and mineralogical data obtained on a selection of chert samples from the quarries in Triadi of Thessaloniki (Central Macedonia, Greece) furtherly support the hypothesis of local production, at least if we consider sample Trd 1-5 composed of only quartz.
In the case of samples with moderate ${ }^{18} \mathrm{O}$ enrichment, several causes must be considered to explain their values. Sample 3-3 $\left(\delta^{18} \mathrm{O}=18.6 \%\right)$ has a chemical composition quite close to that of Roman glass decolourised by the addition of Mn [45]; sample 6-3 $\left(\delta^{18} \mathrm{O}=17.3 \%\right)$ is chemically comparable to "Group 2" of Foy et al. [22], and its suggested age (6th century AD) matches the chronological diffusion of the reference group. However, both samples have $\delta^{18} \mathrm{O}$ higher than the average "Roman" or "HIMT" values.

In view of the high $\mathrm{Na}_{2} \mathrm{O}$ content of samples 3-3 and 6-3 (Table 4), ${ }^{18} \mathrm{O}$ enrichment may be explained by remelting of previous glass with addition of further amounts of natron as flux, which causes an increase in $\mathrm{Na}_{2} \mathrm{O}$ concentration and in the ${ }^{18} \mathrm{O}$ content of the final products.

Apart from their slightly higher $\delta^{18} \mathrm{O}$ values (16.1 and $16.4 \%$, resp.), samples 3-4 and 10-4 show quite different chemical compositions. Sample 3-4 is chemically comparable with "Group 2" [22], the chronological diffusion of which also matches the age proposed (5th-6th centuries $\mathrm{AD}$ ), whereas sample 10-4 is similar to Roman glass, 1st-3rd centuries Ad in age, although the presence of $\mathrm{Cu}$ and $\mathrm{Pb}$ may also indicate recycling of coloured and opaque glass, as in the case of sample 7-1. Both samples may be produced in local secondary workshops, by recycling previous glass (perhaps from the Levantine area), with the addition of further amounts of natron as flux, as suggested by their high $\mathrm{Na}_{2} \mathrm{O}$ content (Table 4), thus increasing the ${ }^{18} \mathrm{O}$ content of the final product.

According to its chemical composition, sample 13-4 (Table $4 ; \delta^{18} \mathrm{O}=17.3 \%$ ) was obtained with soda ash as flux, as deduced from its high $\mathrm{K}_{2} \mathrm{O}, \mathrm{MgO}$, and $\mathrm{P}_{2} \mathrm{O}_{5}$ contents. We suggest a different starting material for this sample, as in the case of other soda plant ash glass identified in the Greek assemblage.

Lastly, sample 8-4 from Thessaloniki has $\delta^{18} \mathrm{O}$ of $15.6 \%$, that is, within the average Roman values, suggesting the use of Belus or Volturno sand and Egyptian natron as raw materials, but its chemical composition is comparable to that of glass produced with soda plant ash as flux. The chronological diffusion of soda ash glass in Europe and Mediterranean area $[4,41]$ excludes a Roman age for this sample and chemical comparisons with 3 rd-7th-century soda ash glass from Iraq $[42,43]$, where plant ash continued to be used as flux throughout the period of natron dominance in the West [4], have not shown any consistency with the present sample. Therefore, great uncertainty remains in the case of sample 84 , as regards both its age and provenance, also in view of the heavily enriched oxygen signatures of other soda ash samples identified here (Table 4). However, sample 8-4 differs from the others due to its lower $\mathrm{SiO}_{2}(61.6 \mathrm{wt} \%)$ and higher $\mathrm{Al}_{2} \mathrm{O}_{3}$ (3.90 wt\%), which suggest a different silica source, probably a silica sand rich in feldspars. This source may be characterised by a less positive oxygen signature, probably related to the feldspars content of the sand, which influences the ${ }^{18} \mathrm{O}$ content of the final product. This hypothesis is also supported by the isotopic and chemical signatures of sample 13-4. Obtained again with soda plant ash as flux, this sample has $\mathrm{Al}_{2} \mathrm{O}_{3}$ content intermediate between that of sample 8-4 and all other Greek soda ash samples and consequently shows an intermediate $\delta^{18} \mathrm{O}$ value. 


\section{Conclusions}

The results of the present study emphasize the importance of measuring the oxygen isotopic and chemical compositions of glass samples in order to constrain some features such as age, raw materials, and production technology. Comparisons of our isotopic and chemical data with those reported in the literature, particularly in the case of glass from the Levantine area, are of particular interest as regards the trading of raw glass to secondary workshops in Greece, although for some samples, obtained with soda ash as flux and heavily enriched in ${ }^{18} \mathrm{O}$, production from local raw materials cannot be completely excluded.

In summary, the thirty-nine glass samples from northern Greece studied here have oxygen isotopic compositions which allow them to be subdivided into three groups.

The first is composed of twenty-nine samples (several from Thessaloniki and all those from Maroneia) with $\delta^{18} \mathrm{O}$ values equal or very close to the mean value of Roman glasses from European and Middle Eastern areas. These similarities imply their production with raw materials with equal or very close oxygen isotopic composition, such as sand from the rivers Belus in Palestine and Volturno in Italy, as suggested by Pliny the Elder. In contrast with the remarkable isotopic homogeneity, heterogeneous chemical compositions allow the subdivision of these samples into several subgroups, which are compared with major compositional groups identified in the Western Mediterranean during the first millennium $\mathrm{AD}$.

Seven samples from Thessaloniki and all the samples from Maroneia show chemical similarity with "Group 2" of Foy et al. [22], while one sample shows chemical similarity with HIMT glass. Accordingly, their age should be constrained to the late Antique period for the Thessaloniki glass and confirmed for the Maroneia samples (i.e., 4th-6th centuries AD). Nine samples from Thessaloniki are chemically comparable with Roman glass, although they differ in colouring/decolouring elements and recycling indicators. In particular, in some samples the identification of manganese, intentionally added as a decolourant, allows us to constrain their age according to the chronological diffusion reported in the literature of this decolourant, that is, from the 3 rd to 4 th centuries AD. Lastly, three samples from Thessaloniki (1st-6th centuries AD) with $\delta^{18} \mathrm{O}$ values comparable with "Roman" values have chemical compositions very different from "typical" Roman glass, suggesting different production technologies.

The second isotopic group is composed of four samples from Thessaloniki, showing heavily enriched $\delta^{18} \mathrm{O}$ values (20.5 to $22.7 \%$ o); their chemical analyses indicate that they were obtained using soda ash as flux, which has little effect on the final oxygen isotopic composition of glass. These high $\delta^{18} \mathrm{O}$ values may be explained by the use of silica raw materials with heavy ${ }^{18} \mathrm{O}$ enrichment such as chert, which is also found in the Thessaloniki region. Therefore, these samples may be the product of local glass factories.

The third group is composed of five samples from Thessaloniki, showing moderate ${ }^{18} \mathrm{O}$ enrichment (16.1 to $18.6 \%$ ).
From the chemical point of view, four samples are natron glass with compositions similar to Roman or "weak" HIMT groups, and one is a soda ash glass. In the case of natron glass, the moderate ${ }^{18} \mathrm{O}$ enrichment may be obtained by recycling glass (perhaps from the Levantine area) in local secondary workshops, with the addition of further amounts of natron as flux, as suggested by their high $\mathrm{Na}_{2} \mathrm{O}$ contents. In the case of soda ash, the moderate ${ }^{18} \mathrm{O}$ enrichment, with respect to other Greek soda ash glass, may be due to the use of less positive silica source.

In conclusion, these interesting results, the first obtained on glass samples from northern Greece, support trades and commercial exchanges between the Near East and Greece and suggest, although further data are required to confirm it, that the "fingerprint" of Greek glass production could be related to the use of local chert and soda ash, as possible raw materials.

\section{Conflicts of Interest}

The authors declare that there are no conflicts of interest regarding the publication of this paper.

\section{Acknowledgments}

The authors are grateful to D. Grammenos, director of the Archaeological Museum of Thessaloniki, for providing glass samples from Thessaloniki. R. Carampin (Istituto di Geoscienze e Georisorse, Sezione di Padova, CNR), F. Gallo (Dipartimento dei Beni Culturali, Università di Padova), and D. Pasqual (Dipartimento di Geoscienze, Università di Padova) are thanked for their kind support to execution of chemical analyses. Financial support was provided by "Ex 60\%" funds of the University of Padova (principal investigator: Alberta Silvestri).

\section{References}

[1] R. Newton and D. Davison, Conservation of Glass, ButterworthHeinemann, Oxford, UK, 1999.

[2] R. H. Brill, R. N. Clayton, T. K. Mayeda, and C. P. Stapleton, "Oxygen isotope analyses of early glasses," in Chemical Analyses of Early Glasses, R. H. Brill, Ed., vol. 2, pp. 303-322, Corning Museum of Glass, New York, NY, USA, 1999.

[3] A. Silvestri, A. Longinelli, and G. Molin, " $\delta^{18} \mathrm{O}$ measurements of archaeological glass (Roman to Modern age) and raw materials: possible interpretation," Journal of Archaeological Science, vol. 37, no. 3, pp. 549-560, 2010.

[4] M. S. Tite, A. Shortland, Y. Maniatis, D. Kavoussanaki, and S. A. Harris, "The composition of the soda-rich and mixed alkali plant ashes used in the production of glass," Journal of Archaeological Science, vol. 33, no. 9, pp. 1284-1292, 2006.

[5] C. Antonaras, "Glass working in Roman and early Christian Thessaloniki: older and more recent finds," in Proceedings of the History, Technology and Conservation of Ancient Metals Glasses and Enamels International Symposium, Athens, Greece, November 2011.

[6] I. Friedman and J. R. O’Neil, "Compilation of stable isotope fractionation factors of geochemical interest," in Data of 
Geochemistry, Geological Survey Professional Paper 440-KK, chapter KK, 1977.

[7] A. Silvestri and A. Marcante, "The glass of Nogara (Verona): a "window" on production technology of mid-Medieval times in Northern Italy," Journal of Archaeological Science, vol. 38, no. 10, pp. 2509-2522, 2011.

[8] S. Alberta, M. Gianmario, and P. Valentina, "The stained glass window of the southern transept of St. Anthony's Basilica (Padova, Italy): study of glasses and grisaille paint layers," Spectrochimica Acta-Part B Atomic Spectroscopy, vol. 66, no. 1, pp. 81-87, 2011.

[9] K. Govindaraju, "Compilation of working values and sample description for 383 geostandards," Geostandards Newsletter, vol. 18, pp. 1-158, 1994.

[10] A. Savitzky and M. J. E. Golay, "Smoothing and differentiation of data by simplified least squares procedures," Analytical Chemistry, vol. 36, no. 8, pp. 1627-1639, 1964.

[11] J. Henderson, J. A. Evans, H. J. Sloane, M. J. Leng, and C. Doherty, "The use of oxygen, strontium and lead isotopes to provenance ancient glasses in the Middle East," Journal of Archaeological Science, vol. 32, no. 5, pp. 665-673, 2005.

[12] K. A. Leslie, I. C. Freestone, D. Lowry, and M. Thirlwall, "The provenance and technology of Near Eastern glass: oxygen isotopes by laser fluorination as a complement to strontium," Archaeometry, vol. 48, no. 2, pp. 253-270, 2006.

[13] R. H. Brill, "Scientific investigations of the Jalame glass and related finds," in Excavations at Jalame, Site of a Glass Factory in Late Roman Palestine, G. D. Wienberg, Ed., pp. 257-293, University of Missouri Press, Columbia, Mo, USA, 1988.

[14] M. Pomerancblum, "The distribution of heavy minerals and their hydraulic equivalents in sediments of the Mediterranean continental shelf of Israel," SEPM Journal of Sedimentary Research, vol. 36, pp. 162-174, 1966.

[15] D. J. Stanley, Y. Mart, and Y. Nir, "Clay mineral distributions to interpret Nile cell provenance and dispersal: II. Coastal plain from Nile delta to northern Israel," Journal of Coastal Research, vol. 13, no. 2, pp. 506-533, 1997.

[16] M. B. Hatzopoulos and L. D. Loukopoulou, Morrylos, Centre de Recherches de l'Antiquité Grecque et Romaine, Athenes, Greece, 1989.

[17] E. Dotsika, D. Poutoukis, I. Tzavidopoulos, Y. Maniatis, D. Ignatiadou, and B. Raco, "A natron source at Pikrolimni Lake in Greece? Geochemical evidence," Journal of Geochemical Exploration, vol. 103, no. 2-3, pp. 133-143, 2009.

[18] H. E. Foster and C. M. Jackson, "The composition of "naturally coloured" late Roman vessel glass from Britain and the implications for models of glass production and supply," Journal of Archaeological Science, vol. 36, no. 2, pp. 189-204, 2009.

[19] I. C. Freestone, "Appendix: chemical analysis of 'raw' glass fragments," in Excavations at Carthage, Volume. II,1. The Circular Harbour, North Side. The Site and Finds Other than Pottery, H. R. Hurst, Ed., British Academy Monographs in Archaeology, N॰4, p. 290, Oxford University Press, Oxford, UK, 1994.

[20] I. C. Freestone, M. Ponting, and M. J. Hughes, "The origins of Byzantine glass from Maroni Petrera, Cyprus," Archaeometry, vol. 44, no. 2, pp. 257-272, 2002.

[21] D. C. W. Sanderson, J. R. Hunter, and S. E. Warren, "Energy dispersive X-ray fluorescence analysis of 1st millennium ad glass from Britain," Journal of Archaeological Science, vol. 11, no. 1, pp. 53-69, 1984.
[22] D. Foy, M. Picon, M. Vichy, and V. Thirion-Merle, "Caractérisation des verres de la fin de l'Antiquité en Méditerranée occidentale: l'émergence de nouveaux courants commerciaux," in Échanges et Commerce du Verre dans le Monde Antique, D. Foy and M. D. Nenna, Eds., Actes du Colloque de l'Association Française pour l'Archéologie du Verre, Aix-en-Provence et Marseille, June 2001, pp. 41-85, Monique Mergoil, Montagnac, France, 2003.

[23] D. Rosenow and T. Rehren, "Herding cats: Roman to Late Antique glass groups from Bubastis, northern Egypt," Journal of Archaeological Science, vol. 49, no. 1, pp. 170-184, 2014.

[24] P. Mirti, A. Casoli, and L. Appolonia, "Scientific analysis of roman glass from augusta praetoria," Archaeometry, vol. 35, no. 2, pp. 225-240, 1993.

[25] A. Silvestri, G. Molin, and G. Salviulo, "Roman and medieval glass from the Italian area: bulk characterization and relationships with production technologies," Archaeometry, vol. 47, no. 4, pp. 797-816, 2005.

[26] A. Silvestri, S. Tonietto, and G. Molin, "The palaeo-Christian glass mosaic of St. Prosdocimus (Padova, Italy): archaeometric characterisation of 'gold' tesserae," Journal of Archaeological Science, vol. 38, no. 12, pp. 3402-3414, 2011.

[27] F. Gallo and A. Silvestri, "Medieval glass from Rocca di Asolo (northern italy): an archaeometric study," Archaeometry, vol. 54, no. 6, pp. 1023-1039, 2012.

[28] F. Gallo, A. Marcante, A. Silvestri, and G. Molin, "The glass of the "Casa delle Bestie Ferite": a first systematic archaeometric study on Late Roman vessels from Aquileia," Journal of Archaeological Science, vol. 41, pp. 7-20, 2014.

[29] S. Maltoni, T. Chinni, M. Vandini, E. Cirelli, A. Silvestri, and G. Molin, "Archaeological and archaeometric study of the glass finds from the ancient harbour of Classe (Ravenna-Italy): new evidence," Heritage Science, vol. 3, no. 1, article 13, 2015.

[30] A. Ceglia, P. Cosyns, K. Nys, H. Terryn, H. Thienpont, and W. Meulebroeck, "Late antique glass distribution and consumption in Cyprus: a chemical study," Journal of Archaeological Science, vol. 61, pp. 213-222, 2015.

[31] N. Schibille, A. Sterrett-Krause, and I. C. Freestone, "Glass groups, glass supply and recycling in late Roman Carthage," Archaeological and Anthropological Sciences, pp. 1-19, 2016.

[32] A. Cholakova, T. Rehren, and I. C. Freestone, "Compositional identification of 6th c. AD glass from the Lower Danube," Journal of Archaeological Science: Reports, vol. 7, pp. 625-632, 2016.

[33] S. Conte, T. Chinni, R. Arletti, and M. Vandini, "Butrint (Albania) between eastern and western Mediterranean glass production: EMPA and LA-ICP-MS of late antique and early medieval finds," Journal of Archaeological Science, vol. 49, no. 1, pp. 6-20, 2014.

[34] I. C. Freestone, S. Wolf, and M. Thirlwall, "The production of HIMT glass: elemental and isotopic evidence," in Annales du $16 e$ Congrès de l'Association Internationale pour l'Histoire du Verre (AIHV '05), pp. 153-157, London, UK, 2005.

[35] M. D. Nenna, M. Picon, and M. Vichy, "Ateliers primaries et secondaries en Egypte à l'époque gréco-romaine," in La Route du Verre. Ateliers Primaires et Secondaires du Second Millénaire av. J.-C. au Moyen Âge, M. D. Nenna, Ed., vol. 33, pp. 97-112, Travaux de la Maison de l'Orient Méditerranéen, 2000.

[36] C. M. Jackson, "Making colourless glass in the Roman period," Archaeometry, vol. 47, no. 4, pp. 763-780, 2005.

[37] E. V. Sayre, "The intentional use of antimony and manganese in ancient glasses," in Advances in Glass Technology Part 2, F. R. 
Matson and G. Rindone, Eds., pp. 263-282, Plenum Press, New York, NY, USA, 1963.

[38] H. E. Foster and C. M. Jackson, "The composition of late Romano-British colourless vessel glass: glass production and consumption," Journal of Archaeological Science, vol. 37, no. 12, pp. 3068-3080, 2010.

[39] J. Henderson, "The raw materials of early glass production," Oxford Journal of Archaeology, vol. 4, no. 3, pp. 267-291, 1985.

[40] B. Gratuze and K. Janssens, "Provenance analysis of glass artefacts," in Non-Destructive Microanalysis of Cultural Heritage Materials, K. Janssens and R. Van Grieken, Eds., pp. 663-712, Elsevier, Amsterdam, The Netherlands, 2004.

[41] J. Henderson, "Tradition and experiment in first millennium A.D. glass production-the emergence of early Islamic glass technology in late antiquity," Accounts of Chemical Research, vol. 35, no. 8, pp. 594-602, 2002.

[42] P. Mirti, M. Pace, M. M. Negro Ponzi, and M. Aceto, "ICP-MS analysis of glass fragments of Parthian and Sasanian epoch from Seleucia and Veh Ardašīr (Central Iraq)," Archaeometry, vol. 50, no. 3, pp. 429-450, 2008.

[43] P. Mirti, M. Pace, M. Malandrino, and M. N. Ponzi, "Sasanian glass from Veh Ardaširr: new evidences by ICP-MS analysis," Journal of Archaeological Science, vol. 36, no. 4, pp. 1061-1069, 2009.

[44] J. Hoefs, Stable Isotope Geochemistry, Springer, Berlin, Germany, 5th edition, 2004.

[45] A. Silvestri, G. Molin, and G. Salviulo, "The colourless glass of Iulia Felix," Journal of Archaeological Science, vol. 35, no. 2, pp. 331-341, 2008. 

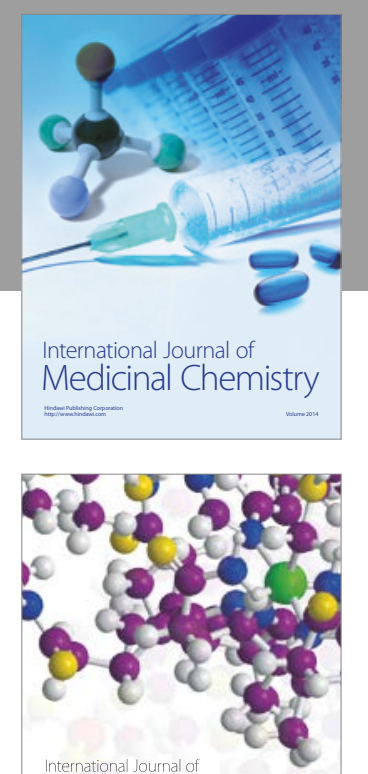

Carbohydrate Chemistry

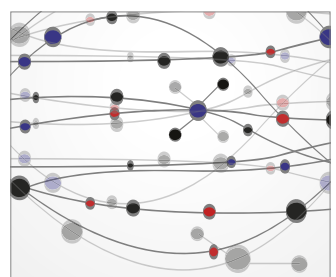

The Scientific World Journal
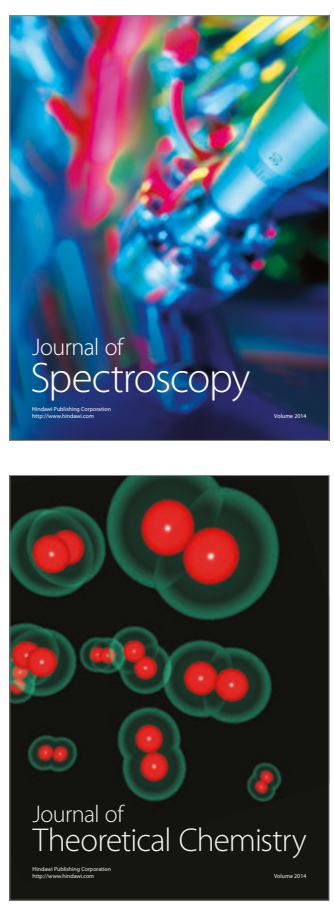
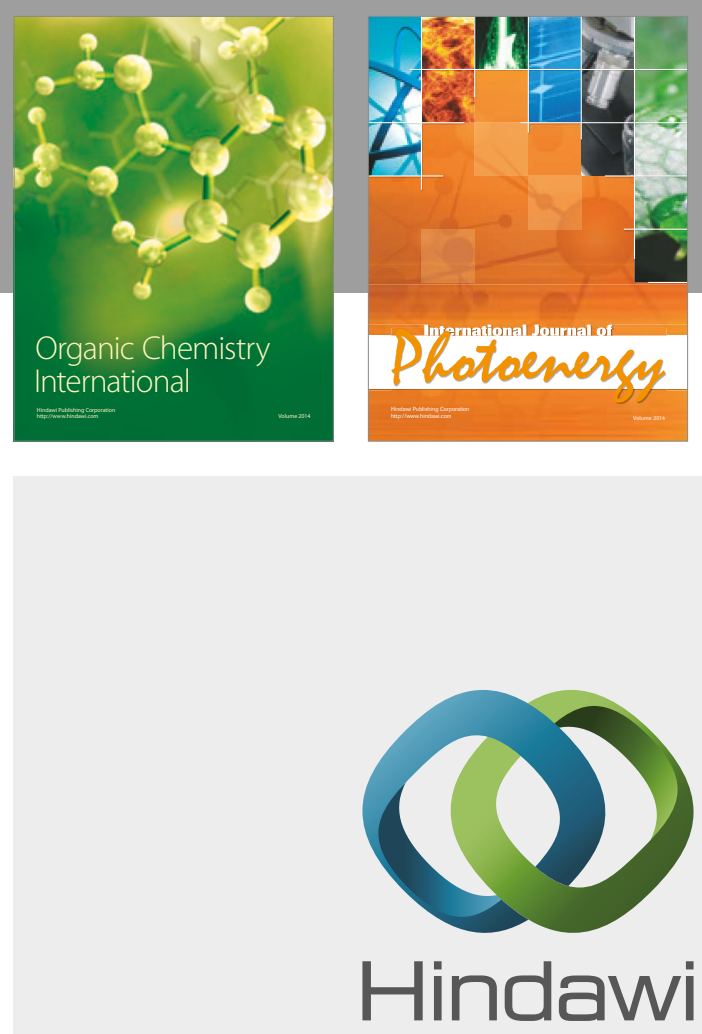

Submit your manuscripts at

https://www.hindawi.com

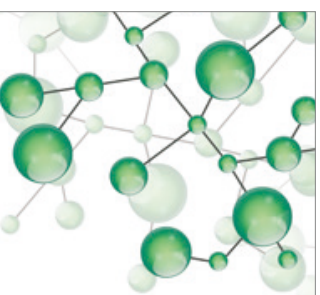

International Journal of

Inorganic Chemistry

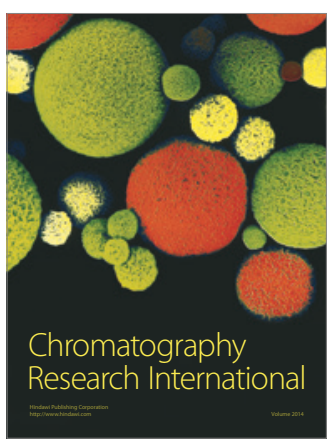

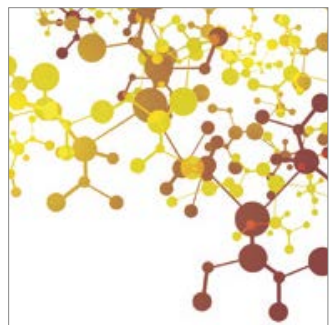

Applied Chemistry
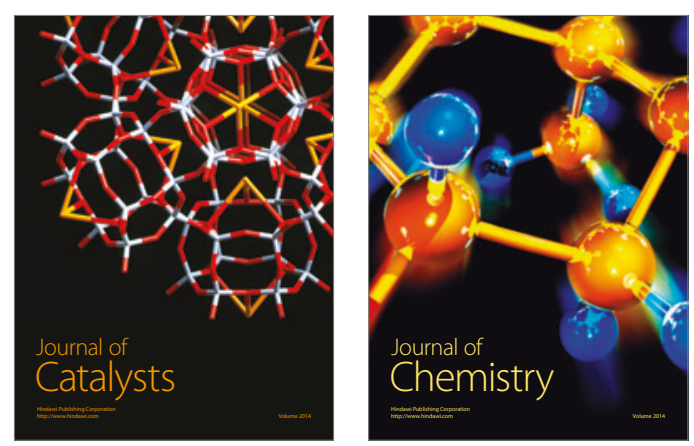
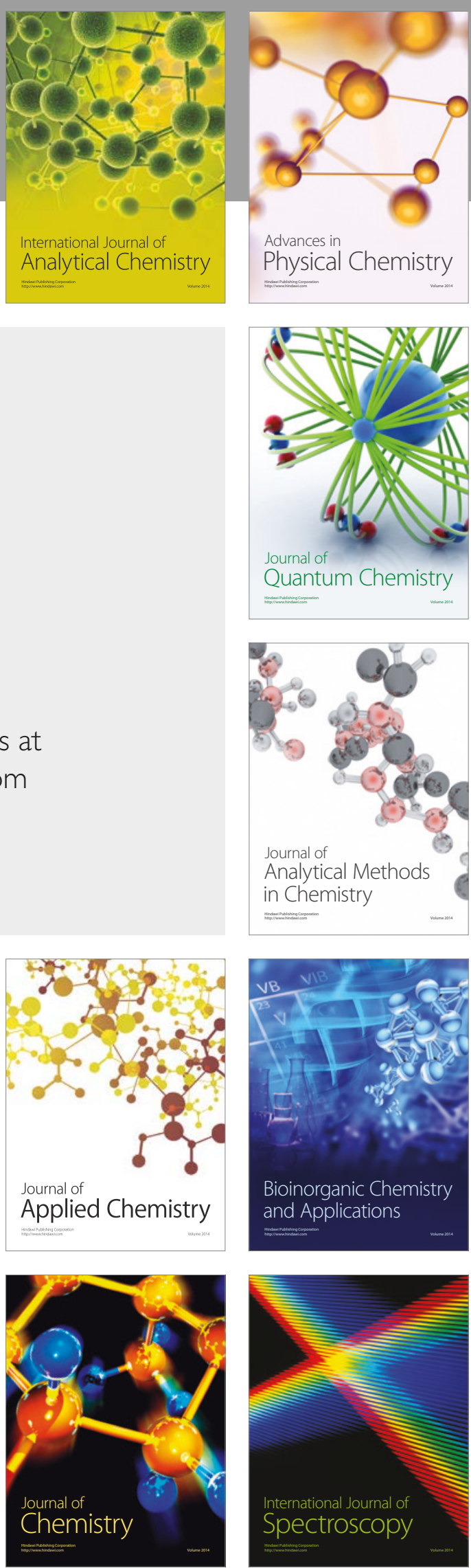